
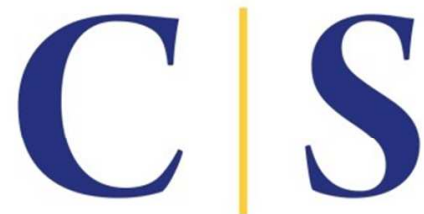

JOURNAL OF THE AMERICAN CHEMICAL SOCIETY

\title{
Supramolecular Double Helix Formation by Diastereoisomeric Conformations of Configurationally Enantiomeric Macrocycles
}

Avik Samanta, Zhichang Liu, Siva Krishna Mohan Nalluri, Yu Zhang, George C. Schatz and J. Fraser Stoddart ${ }^{\dagger}, *$

${ }^{\dagger}$ Department of Chemistry, Northwestern University, 2145 Sheridan Road, Evanston, Illinois 60208-3113, USA

*E-mail: stoddart@northwestern.edu

\section{SUPPORTING INFORMATION}

\section{Table of Contents}

Section A. Materials / General Methods / Instrumentation....................................S2

Section B. Syntheses...........................................................................

Section C. NMR Spectroscopies...................................................S9

Section D. Variable-Temperature CD of $R$-2BPDI...................................S26

Section E. Crystallographic Characterization.............................................

Section F. Density Function Theory (DFT) Structure Optimization........................S29

Section G. References.................................................................S32 


\section{Section A. Materials / General Methods / Instrumentation}

All the reagents were purchased from the commercial suppliers and used without undergoing further purification. $(R R)$ and $(S S)$-trans-1,2-cyclohexanediamines were prepared by resolving racemic trans-1,2-cyclohexanediamine with $L$-(+)-tartaric acid, as described in the literature. ${ }^{\mathrm{S} 1}$ Solvents (THF, DMF, $\mathrm{CH}_{2} \mathrm{Cl}_{2}$ ) were dried using a commercial solvent purification system. All reactions were performed under a nitrogen atmosphere, unless stated otherwise. Thin layer chromatography (TLC) was performed on silica gel 60 F254. Column chromatography was carried out on silica gel 60F (Merck 9385, 0.040-0.063 mm). High-resolution mass spectra were measured on an Agilent 6210 Time of Flight (TOF) LC-MS, using an ESI source, coupled with Agilent 1100 HPLC stack, using direct infusion $(0.6 \mathrm{~mL} / \mathrm{min})$. Nuclear magnetic resonance (NMR) spectra were recorded on a Bruker Avance 600 and Varian P-Inova 500 spectrometers at $298 \mathrm{~K}$, unless mentioned otherwise, with working frequencies of 600.168 and $499.373 \mathrm{MHz}$ for ${ }^{1} \mathrm{H}$, as well as 150.928 and $125.579 \mathrm{MHz}$ for ${ }^{13} \mathrm{C}$ nuclei, respectively. Chemical shifts are reported in ppm relative to the signals corresponding to the residual non-deuterated solvents (TMS: $\delta=0.00 \mathrm{ppm}$ ). Coupling constants are recorded in Hertz (Hz). All ${ }^{13} \mathrm{C}$ NMR spectra were recorded with the simultaneous decoupling of proton nuclei. The following abbreviations were used to categorize the signal multiplicities: $\mathrm{s}$, singlet; $\mathrm{d}$, doublet; $\mathrm{t}$, triplet; $\mathrm{b}$, broad peaks; $\mathrm{m}$, multiplet or overlapping peaks. UV/Vis/NIR absorption spectra were recorded using a UV-3600 Shimadzu spectrophotometer. Circular dichroism (CD) measurements were carried out on a Jasco J-815 spectrometer over a variable temperature range. Cyclic voltammetry (CV) experiments were performed at room temperature in argon-purged solutions of $\mathrm{MeCN}$ with a Gamry Multipurpose instrument (Reference 600) interfaced to a PC. All CV experiments were performed using a glassy carbon working electrode $\left(0.071 \mathrm{~cm}^{2}\right)$. The electrode surface was polished routinely with $0.05 \mu \mathrm{m}$ alumina-water slurry on a felt surface immediately before use. The counter electrode was a Pt coil and the reference electrode was an $\mathrm{Ag} / \mathrm{AgCl}$ electrode. The concentration of the sample and supporting electrolyte, tetrabutylammonium hexafluorophosphate $\left(\mathrm{TBAPF}_{6}\right)$, were $1.0 \mathrm{mM}$ and $0.1 \mathrm{M}$, respectively. The $\mathrm{CV}$ cell was dried in an oven immediately before use, and argon was continually flushed through the cell as it was cooled down to room temperature to avoid condensation of water. 


\section{Section B. Syntheses}
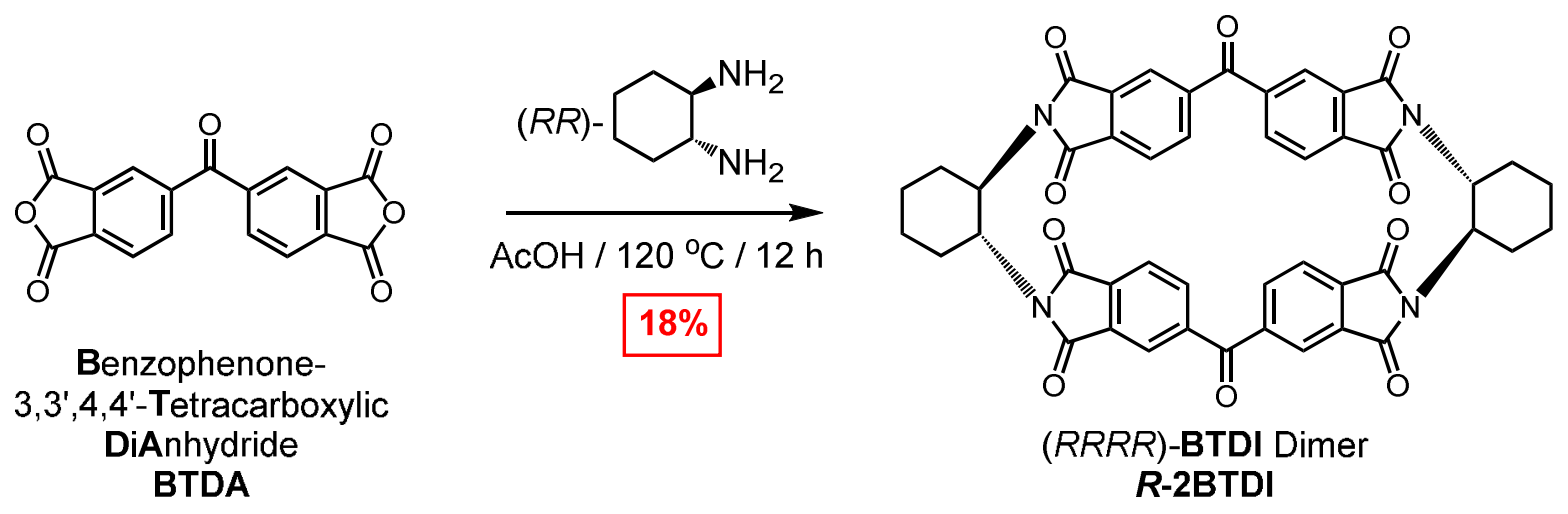

Scheme S1. Synthesis of $\boldsymbol{R}$-2BTDI

R-2BTDI (Scheme S1). A warm solution of (RR)-trans-1,2-cyclohexanediamine (1.07 g, 9.4 $\mathrm{mmol})$ in glacial $\mathrm{AcOH}(10 \mathrm{~mL})$ was added quickly to a suspension of benzophenone-3,3',4,4'tetracarboxylic dianhydride (BTDA, $3.00 \mathrm{~g}, 9.3 \mathrm{mmol})$ in glacial $\mathrm{AcOH}(150 \mathrm{~mL})$ with vigorous stirring at $110^{\circ} \mathrm{C}$. The resulting light yellow reaction mixture was heated at $120^{\circ} \mathrm{C}$ while stirring overnight and the glacial $\mathrm{AcOH}$ was evaporated under reduced pressure $(\sim 10 \mathrm{mbar})$ at $70{ }^{\circ} \mathrm{C}$. The yellow residue was dissolved in $\mathrm{CH}_{2} \mathrm{Cl}_{2}$ and purified by flash column chromatography over silica gel $\left(\mathrm{CH}_{2} \mathrm{Cl}_{2} /\right.$ EtOAc, $0-20 \%$ EtOAc) to afford $\boldsymbol{R}$-2BTDI $(0.66 \mathrm{~g}, 0.83 \mathrm{mmol})$ in $18 \%$ yield as a white solid mixture, which was shown by NMR spectroscopy to be a mixture of inseparable conformational diastereoisomers. The ratio of $\boldsymbol{R}$-Diastereoisomer-1 and $\boldsymbol{R}$-Diastereoisomer-2 was found to be 1.5:1 on the basis of the integration of the ${ }^{1} \mathrm{H}$ NMR peaks in $\mathrm{CD}_{3} \mathrm{SOCD}_{3} .{ }^{1} \mathrm{H}$ $\operatorname{NMR}\left(500 \mathrm{MHz}, \mathrm{CD}_{3} \mathrm{SOCD}_{3}, 25^{\circ} \mathrm{C}\right): \boldsymbol{R}$-Diastereoisomer-1: $\delta=8.26-8.22(\mathrm{~d}, J=7.7 \mathrm{~Hz}, 4 \mathrm{H})$, $8.06-8.01$ (d, $J=7.7 \mathrm{~Hz}, 4 \mathrm{H}), 7.42-7.38(\mathrm{~s}, 4 \mathrm{H}), 4.61-4.34(\mathrm{~m}, 4 \mathrm{H}), 2.8-2.73(\mathrm{~m}, 4 \mathrm{H}), 2.05$ - $1.96(\mathrm{~m}, 4 \mathrm{H}), 1.91-1.85$ (m, 4H), $1.49-1.39$ (m, 4H); $\boldsymbol{R}$-Diastereoisomer-2: $\delta=8.30-8.28$ (d, $J=7.8 \mathrm{~Hz}, 2 \mathrm{H}), 8.15-8.13$ (s, 2H), $8.10-8.07$ (d, $J=7.7 \mathrm{~Hz}, 2 \mathrm{H}), 7.76-7.72$ (d, $J=7.6$ $\mathrm{Hz}, 2 \mathrm{H}), 7.50-7.46$ (d, J=7.6 Hz, 2H), $7.30-7.26(\mathrm{~s}, 2 \mathrm{H}), 7.42-7.38$ (s, 4H), $4.61-4.34$ (m, $4 \mathrm{H}), 2.8-2.73(\mathrm{~m}, 4 \mathrm{H}), 2.05-1.96(\mathrm{~m}, 4 \mathrm{H}), 1.91-1.85(\mathrm{~m}, 4 \mathrm{H}), 1.49-1.39(\mathrm{~m}, 4 \mathrm{H}) .{ }^{13} \mathrm{C}$ NMR (125 MHz, $\left.\mathrm{CD}_{3} \mathrm{SOCD}_{3}, 25^{\circ} \mathrm{C}\right): \boldsymbol{R}$-Diastereoisomer-1: $\delta=191.8,167.13,167.0,140.4$, 135.3, 134.6, 130.4, 123.7, 123.3, 51.9, 26.9, 24.6; $\boldsymbol{R}$-Diastereoisomer-2: $\delta=193.9,167.2$, $167.09,142.2,141.9,135.1,134.4,132.8,131.9,130.1,123.82,122.37,122.3,52.2,27.2,24.7$. ESI-HRMS $(m / z)$ : calcd for $[M+\mathrm{Cl}]^{-}=835.1807$; found: 835.1805 . 
<smiles>O=C(c1ccc2c(c1)C(=O)OC2=O)c1ccc2c(c1)C(=O)OC2=O</smiles>

BTDA

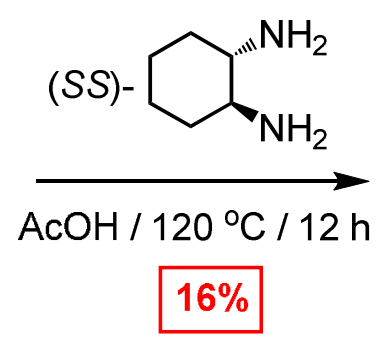

Scheme S2. Synthesis of $\boldsymbol{S}$-2BTDI

S-2BTDI (Scheme S2). The enantiomer (0.29 g, $0.37 \mathrm{mmol})$ was obtained in $16 \%$ yield starting from (SS)-trans-1,2-cyclohexanediamine (0.54 g, $4.7 \mathrm{mmol})$ and benzophenone-3,3',4,4'tetracarboxylic dianhydride (BTDA, $1.50 \mathrm{~g}, 4.65 \mathrm{mmol}$ ) following the same procedure as that described for the synthesis $\boldsymbol{R}$-2BTDI. The spectroscopic data were almost identical to those obtained for $\boldsymbol{R}$-2BTDI, with the exception of the CD spectrum, which was the mirror image of the one observed for the $\boldsymbol{R}$-enantiomer. The ratio of $\boldsymbol{S}$-Diastereoisomer-1 and $\boldsymbol{S}$ Diastereoisomer-2 was also found to be $1.5: 1$ on the basis of the integration of the ${ }^{1} \mathrm{H}$ NMR peaks in $\mathrm{CD}_{3} \mathrm{SOCD}_{3} .{ }^{1} \mathrm{H} \mathrm{NMR}\left(500 \mathrm{MHz}, \mathrm{CD}_{3} \mathrm{SOCD}_{3}, 25{ }^{\circ} \mathrm{C}\right): \boldsymbol{S}$-Diastereoisomer-1: $\delta=8.25$ $-8.21(\mathrm{~d}, J=7.7 \mathrm{~Hz}, 4 \mathrm{H}), 8.05-8.01(\mathrm{~d}, J=7.7 \mathrm{~Hz}, 4 \mathrm{H}), 7.42-7.38(\mathrm{~s}, 4 \mathrm{H}), 4.51-4.36(\mathrm{~m}$, 4H), $2.80-2.65(\mathrm{~m}, 5 \mathrm{H}), 2.05-1.97(\mathrm{~m}, 4 \mathrm{H}), 1.95-1.86(\mathrm{~m}, 4 \mathrm{H}), 1.45-1.35(\mathrm{~m}, 4 \mathrm{H}) ; \boldsymbol{S}-$ Diastereoisomer-2: $\delta=8.31-8.26(\mathrm{~d}, J=7.8 \mathrm{~Hz}, 2 \mathrm{H}), 8.16-8.12(\mathrm{~s}, 2 \mathrm{H}), 8.09-8.07(\mathrm{~d}, J=$ $7.7 \mathrm{~Hz}, 2 \mathrm{H}), 7.76-7.73(\mathrm{~d}, J=7.6 \mathrm{~Hz}, 2 \mathrm{H}), 7.49-7.45(\mathrm{~d}, J=7.6 \mathrm{~Hz}, 2 \mathrm{H}), 7.30-7.26(\mathrm{~s}, 2 \mathrm{H})$, $4.51-4.36(\mathrm{~m}, 4 \mathrm{H}), 2.80-2.65(\mathrm{~m}, 5 \mathrm{H}), 2.05-1.97(\mathrm{~m}, 4 \mathrm{H}), 1.95-1.86(\mathrm{~m}, 4 \mathrm{H}), 1.45-1.35$ $(\mathrm{m}, 4 \mathrm{H}) .{ }^{13} \mathrm{C} \mathrm{NMR}\left(125 \mathrm{MHz}, \mathrm{CD}_{3} \mathrm{SOCD}_{3}, 25{ }^{\circ} \mathrm{C}\right): \boldsymbol{S}$-Diastereoisomer-1: $\delta=191.8,167.13$, 167.03, 140.4, 135.3, 134.6, 130.4, 123.7, 123.3, 51.9, 27.2, 24.6; $\boldsymbol{S}$-Diastereoisomer-2: $\delta=$ $193.9,167.23,167.1,142.2,141.9,135.1,134.5,134.4,132.8,131.9,130.0,123.8,122.4,122.3$, 52.2, 26.9, 24.8. ESI-HRMS $(m / z)$ : calcd for $[M+\mathrm{Cl}]^{-}=835.1807$; found: 835.1815 . 


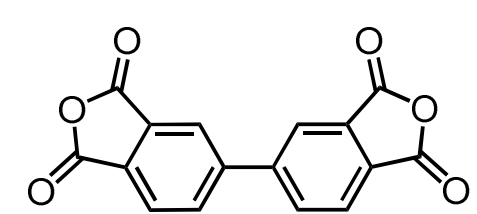

\section{3,3',4,4'-BiPhenyltetracarboxylic \\ DiAnhydride \\ BPDA}

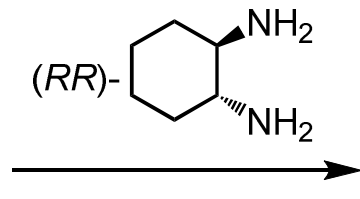

$\mathrm{ACOH} / 120^{\circ} \mathrm{C} / 12 \mathrm{~h}$

$21 \%$

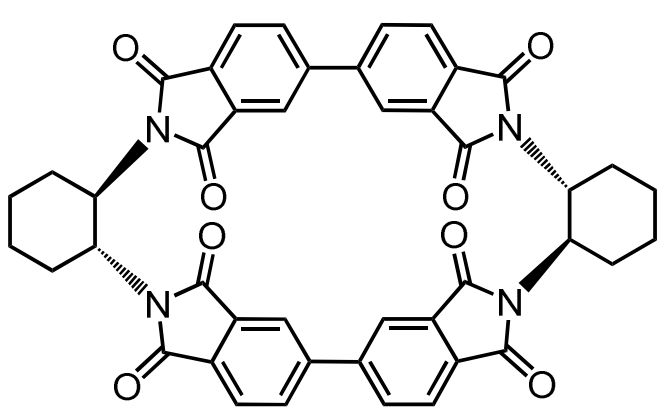

Scheme S3. Synthesis of $\boldsymbol{R}$-2BPDI

(RRRR)-BPDI Dimer

$R$-2BPDI

R-2BPDI (Scheme S3). A warm solution of (RR)-trans-1,2-cyclohexanediamine (0.59 g, $5.15 \mathrm{mmol})$ in glacial $\mathrm{AcOH}(6 \mathrm{~mL})$ was added rapidly to a suspension of biphenyltetracarboxylic dianhydride (BPDA, $1.5 \mathrm{~g}, 5.10 \mathrm{mmol})$ in glacial AcOH (70 mL) with vigorous stirring at $110{ }^{\circ} \mathrm{C}$. The reaction mixture was stirred at $120^{\circ} \mathrm{C}$ overnight and the glacial $\mathrm{AcOH}$ was evaporated under reduced pressure $(\sim 10 \mathrm{mbar})$ at $70^{\circ} \mathrm{C}$. The light yellow residue was dissolved in $\mathrm{CH}_{2} \mathrm{Cl}_{2}$ and purified by flash column chromatography over silica gel $\left(\mathrm{CH}_{2} \mathrm{Cl}_{2} /\right.$ EtOAc, $0-20 \%$ EtOAc) to afford pure $\boldsymbol{R}-2 \mathbf{B P D I}(0.41 \mathrm{~g}, 0.54 \mathrm{mmol})$ as a white solid in $21 \%$ yield. Higher order macrocyclic oligomers were also observed in the reaction mixture. ${ }^{1} \mathrm{H}$ $\operatorname{NMR}\left(500 \mathrm{MHz}, \mathrm{CDCl}_{3}, 25{ }^{\circ} \mathrm{C}\right) \delta=7.90-7.86(\mathrm{~d}, J=7.6 \mathrm{~Hz}, 4 \mathrm{H}), 7.68-7.62(\mathrm{dd}, J=7.7,1.7$ $\mathrm{Hz}, 4 \mathrm{H}), 7.09-7.05(\mathrm{~d}, J=1.4 \mathrm{~Hz}, 4 \mathrm{H}), 4.74-4.44(\mathrm{~m}, 4 \mathrm{H}), 2.92-2.66(\mathrm{~m}, 4 \mathrm{H}), 2.14-2.03$ $(\mathrm{m}, 4 \mathrm{H}), 2.01-1.96 \mathrm{f}(\mathrm{m}, 4 \mathrm{H}), 1.67-1.44(\mathrm{~m}, 4 \mathrm{H}) .{ }^{13} \mathrm{C} \mathrm{NMR}\left(125 \mathrm{MHz}, \mathrm{CDCl}_{3}, 25{ }^{\circ} \mathrm{C}\right) \delta=$ 167.9, 167.8, 145.3, 132.9, 132.3, 131.7, 124.5, 121.7, 52.9, 28.4, 25.5. ESI-HRMS (m/z): calcd for $[M+\mathrm{Cl}]^{-}=779.1909$; found: 779.1917 . 
<smiles>O=C1OC(=O)c2cc(-c3ccc4c(c3)C(=O)OC4=O)ccc21</smiles>

BPDA

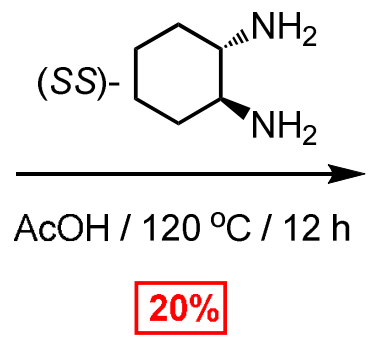

Scheme S4. Synthesis of $\boldsymbol{S}$-2BPDI

$\boldsymbol{S}$-2BPDI (Scheme S4). The enantiomer $\boldsymbol{S}$-2BPDI (0.29 g, $0.51 \mathrm{mmol})$ was obtained in 20\% yield starting from (SS)-trans-1,2-cyclohexanediamine $(0.59 \mathrm{~g}, \quad 5.15 \mathrm{mmol})$ and biphenyltetracarboxylic dianhydride (BPDA, $1.5 \mathrm{~g}, 5.10 \mathrm{mmol}$ ) following the same procedure as that described for $\boldsymbol{R}$-2BPDI. The spectroscopic data are identical with those observed for $\boldsymbol{R}$ 2BPDI, with the exception of the CD spectrum, which is the mirror image of the one observed for $\boldsymbol{R}$-2BPDI. ${ }^{1} \mathrm{H}$ NMR $\left(500 \mathrm{MHz}, \mathrm{CDCl}_{3}, 25{ }^{\circ} \mathrm{C}\right) \delta=7.91-7.85(\mathrm{~d}, J=7.7 \mathrm{~Hz}, 4 \mathrm{H}), 7.68-$ $7.62(\mathrm{dd}, J=7.7,1.6 \mathrm{~Hz}, 4 \mathrm{H}), 7.09-7.05(\mathrm{~d}, J=1.5 \mathrm{~Hz}, 4 \mathrm{H}), 4.74-4.53(\mathrm{~m}, 4 \mathrm{H}), 2.86-2.71$ $(\mathrm{m}, 4 \mathrm{H}), 2.16-2.03(\mathrm{~m}, 4 \mathrm{H}), 2.03-1.93(\mathrm{~m}, 2 \mathrm{H}), 1.65-1.45(\mathrm{~m}, 4 \mathrm{H}) .{ }^{13} \mathrm{C} \mathrm{NMR}(125 \mathrm{MHz}$ $\left.\mathrm{CDCl}_{3}, 25^{\circ} \mathrm{C}\right) \delta 167.84,167.76,145.27,132.97,132.30,131.71,124.46,121.71,52.95,28.43$, 25.47. ESI-HRMS $(m / z)$ : calcd for $[M+\mathrm{Cl}]^{-}=779.1909$; found: 779.1917 . 
<smiles>O=C(c1ccc2c(c1)C(=O)OC2=O)c1ccc2c(c1)C(=O)OC2=O</smiles>

BTDA

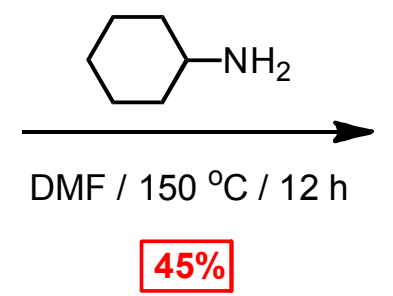<smiles>O=C(c1ccc2c(c1)C(=O)N(C1CCCCC1)C2=O)c1ccc2c(c1)C(=O)N(C1CCCCC1)C2=O</smiles>

Bis(cyclohexyl)benzophenone tetracarboxylic diimide

Scheme S5. Synthesis of BTDI-Ref

BTDI-Ref (Scheme S5). Benzophenone-3,3',4,4'-tetracarboxylic dianhydride (BTDA, $0.32 \mathrm{~g}$, $1.70 \mathrm{mmol})$ and cyclohexylamine $(1.2 \mathrm{~mL}, 10.20 \mathrm{mmol})$ were heated under nitrogen in DMF at $150{ }^{\circ} \mathrm{C}$ for $12 \mathrm{~h}$. The reaction mixture was concentrated under reduced pressure ( 10 mbar) at $70{ }^{\circ} \mathrm{C}$. The yellow residue was dissolved in $\mathrm{CH}_{2} \mathrm{Cl}_{2}$ and purified by flash column chromatography over silica gel $\left(\mathrm{CH}_{2} \mathrm{Cl}_{2} / \mathrm{Me}_{2} \mathrm{CO}, 0-10 \% \mathrm{Me}_{2} \mathrm{CO}\right)$ to afford pure BPDI-Ref $(0.31$ $\mathrm{g}, 0.64 \mathrm{mmol})$ in $65 \%$ yield as a white solid. ${ }^{1} \mathrm{H} \mathrm{NMR}\left(500 \mathrm{MHz}, \mathrm{CDCl}_{3}, 25{ }^{\circ} \mathrm{C}\right) \delta=8.13-8.10$ $(\mathrm{dd}, J=7.6,1.5 \mathrm{~Hz}, 2 \mathrm{H}), 8.10-8.09(\mathrm{~m}, 2 \mathrm{H}), 7.98-7.93(\mathrm{~d}, J=7.2 \mathrm{~Hz}, 2 \mathrm{H}), 4.18-4.09(\mathrm{tt}, J=$ $12.3,3.9 \mathrm{~Hz}, 2 \mathrm{H}), 2.26-2.14(\mathrm{qd}, J=12.5,3.5 \mathrm{~Hz}, 4 \mathrm{H}), 1.91-1.84(\mathrm{dd}, J=10.5,3.2 \mathrm{~Hz}, 4 \mathrm{H})$, $1.77-1.66(\mathrm{~m}, 6 \mathrm{H}), 1.42-1.21(\mathrm{~m}, 6 \mathrm{H}) .{ }^{13} \mathrm{C} \mathrm{NMR}\left(125 \mathrm{MHz}, \mathrm{CDCl}_{3}, 25{ }^{\circ} \mathrm{C}\right) \delta=193.4,167.4$ 167.3, 141.6, 135.5, 135.4, 132.6, 124.2, 123.7, 51.6, 29.9, 26.1, 25.2. . ESI-HRMS: calcd for [M $+\mathrm{H}]^{+} m / z=485.2076$; found: 485.2081 . 
<smiles>C=C1OC(=O)c2cc(-c3ccc4c(c3)C(=O)OC4=O)ccc21</smiles>

BPDA

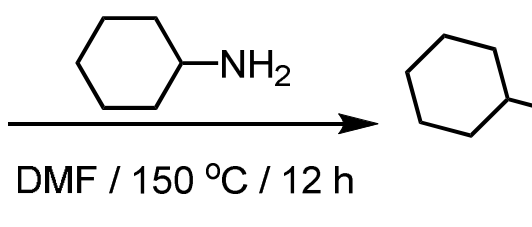

$70 \%$

Scheme S6. Synthesis of BPDI-Ref

BPDI-Ref (Scheme S6). Biphenyltetracarboxylic dianhydride (BPDA, $0.5 \mathrm{~g}, 1.70 \mathrm{mmol}$ ) and cyclohexylamine $(1.2 \mathrm{~mL}, 10.20 \mathrm{mmol})$ were heated under nitrogen in DMF at $150{ }^{\circ} \mathrm{C}$ for $12 \mathrm{~h}$. The solvent was evaporated under reduced pressure $(\sim 10$ mbar $)$ at $70{ }^{\circ} \mathrm{C}$. The yellow residue was dissolved in $\mathrm{CH}_{2} \mathrm{Cl}_{2}$ and purified by flash column chromatography over silica gel $\left(\mathrm{CH}_{2} \mathrm{Cl}_{2} /\right.$ $\left.\mathrm{Me}_{2} \mathrm{CO}, 0-10 \% \mathrm{Me}_{2} \mathrm{CO}\right)$ to afford pure BPDI-Ref $(0.54 \mathrm{~g}, 1.18 \mathrm{mmol})$ as a white solid in $70 \%$ yield. ${ }^{1} \mathrm{H}$ NMR $\left(500 \mathrm{MHz}, \mathrm{CDCl}_{3}, 25{ }^{\circ} \mathrm{C}\right) \delta=8.08-8.03(\mathrm{~d}, J=1.2 \mathrm{~Hz}, 2 \mathrm{H}), 7.95-7.91(\mathrm{~m}$, 4H), $4.19-4.09(\mathrm{tt}, J=12.3,3.8 \mathrm{~Hz}, 2 \mathrm{H}), 2.30-2.15(\mathrm{qd}, J=12.6,3.5 \mathrm{~Hz}, 4 \mathrm{H}), 1.93-1.85(\mathrm{~m}$, 4H), $1.78-1.68(\mathrm{~m}, 6 \mathrm{H}), 1.46-1.23(\mathrm{~m}, 6 \mathrm{H}) .{ }^{13} \mathrm{C} \mathrm{NMR}\left(125 \mathrm{MHz}, \mathrm{CDCl}_{3}, 25{ }^{\circ} \mathrm{C}\right) \delta=168.0$, 145.2, 133.4, 132.8, 131.9, 124.0, 122.0, 51.3, 30.0, 26.2, 25.2. ESI-HRMS: calcd for $[M+\mathrm{H}]^{+}$ $m / z=457.2127$; found: 457.2132 . 


\section{Section D. NMR Spectroscopies}

a) ${ }^{1} \mathrm{H}$ NMR Spectrum of $R-2 \mathrm{BTDI}$ in $\mathrm{CD}_{3} \mathrm{SOCD}_{3}$

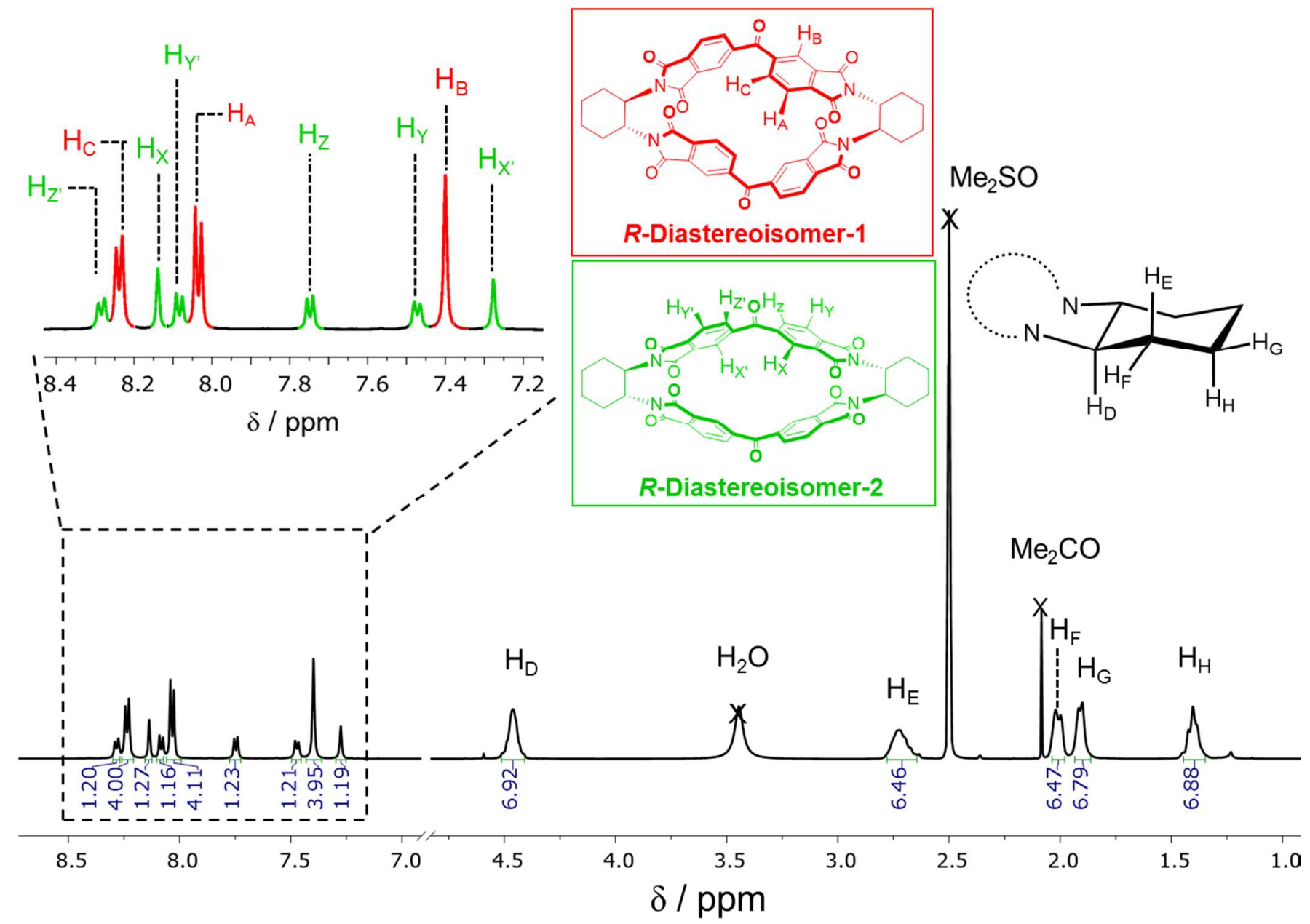

Figure S1. Annotated ${ }^{1} \mathrm{H}$ NMR spectrum (500 MHz, $\mathrm{CD}_{3} \mathrm{SOCD}_{3}, 298 \mathrm{~K}$ ) of $\boldsymbol{R}$-2BTDI 
b) ${ }^{13} \mathrm{C}$ NMR Spectrum of $\mathrm{R}-2 \mathrm{BTDI}$ in $\mathrm{CD}_{3} \mathrm{SOCD}_{3}$
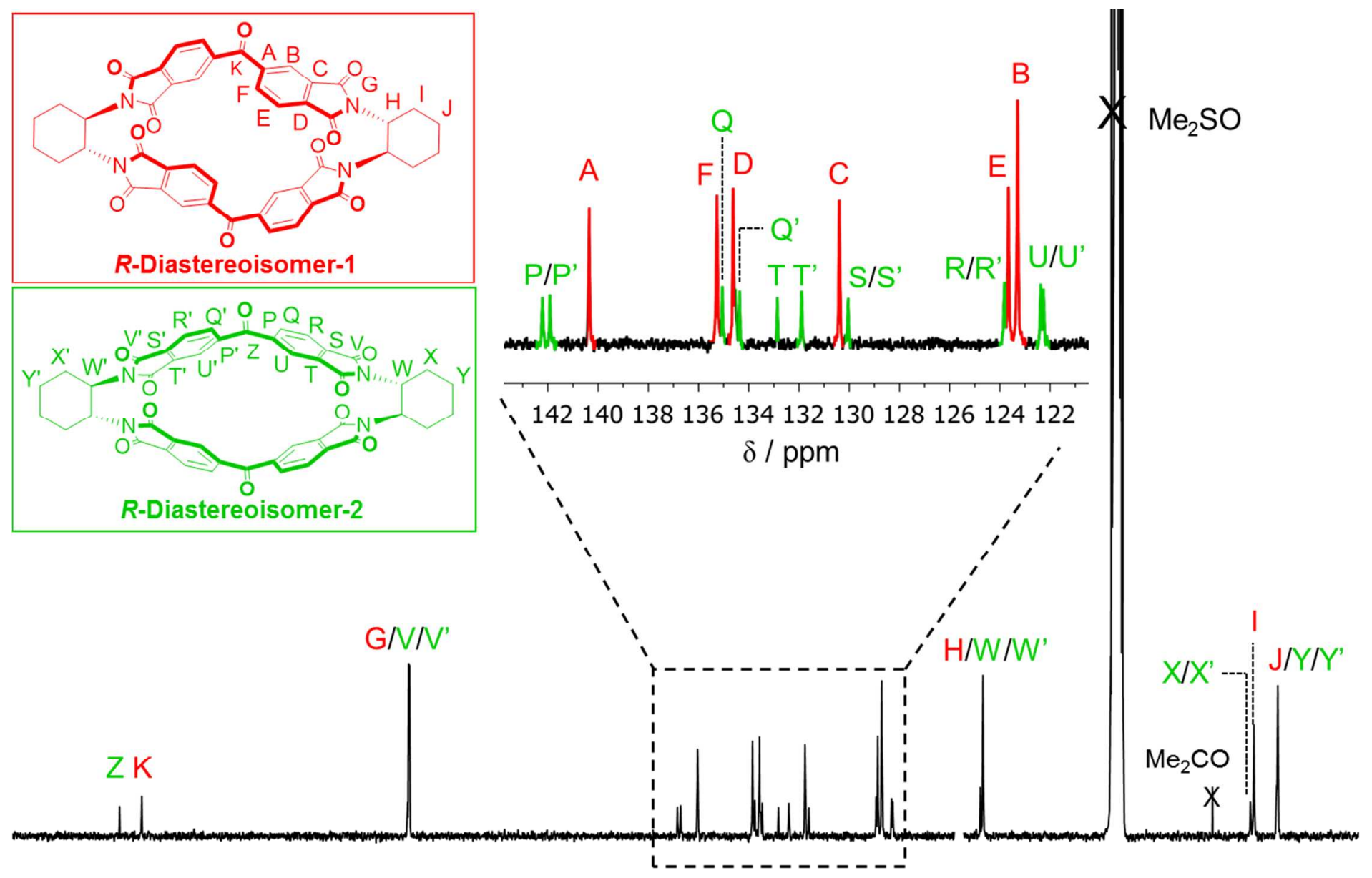

$\begin{array}{lllllllllllllllll}200 & 195 & 190 & 185 & 180 & 175 & 170 & 165 & 160 & 155 & 150 & 145 & 140 & 135 & 130 & 125 & 120\end{array}$

$\delta / \mathrm{ppm}$

Figure S2. Annotated ${ }^{13} \mathrm{C}$ NMR spectrum (500 MHz, $\mathrm{CD}_{3} \mathrm{SOCD}_{3}, 298 \mathrm{~K}$ ) of $\boldsymbol{R}$-2BTDI 
c) Annotated 2D ${ }^{1} \mathrm{H}-{ }^{1} \mathrm{H}$ Correlation (COSY), Nuclear Overhauser Effect (NOESY), ${ }^{1} \mathrm{H}-{ }^{13} \mathrm{C}$ Heteronuclear Single Quantum Coherence (HSQC) and Heteronuclear Multiple Bond Correlation (HMBC) NMR Spectroscopies of $R-2 B P D I$ in $\mathrm{CD}_{3} \mathrm{SOCD}_{3}$ :

The unambiguous assignment of the various methine $(\mathrm{CH})$ and methylene $\left(\mathrm{CH}_{2}\right)$ protons in the dimeric macrocycle $\boldsymbol{R}$-2BTDI was reasoned using 2D Correlation (COSY) and Nuclear Overhauser Effect (NOESY) NMR spectroscopy (Figure S3). The unambiguous assignments of various carbonyl, aromatic and cyclohexano carbons corresponding to the individual BTDI moieties of the macrocycle $\boldsymbol{R}$-2BTDI were deduced (Figure S4). using $2 \mathrm{D}{ }^{1} \mathrm{H}-{ }^{13} \mathrm{C}$ heteronuclear single quantum coherence (HSQC) and heteronuclear multiple bond correlation (HMBC) NMR spectroscopies.
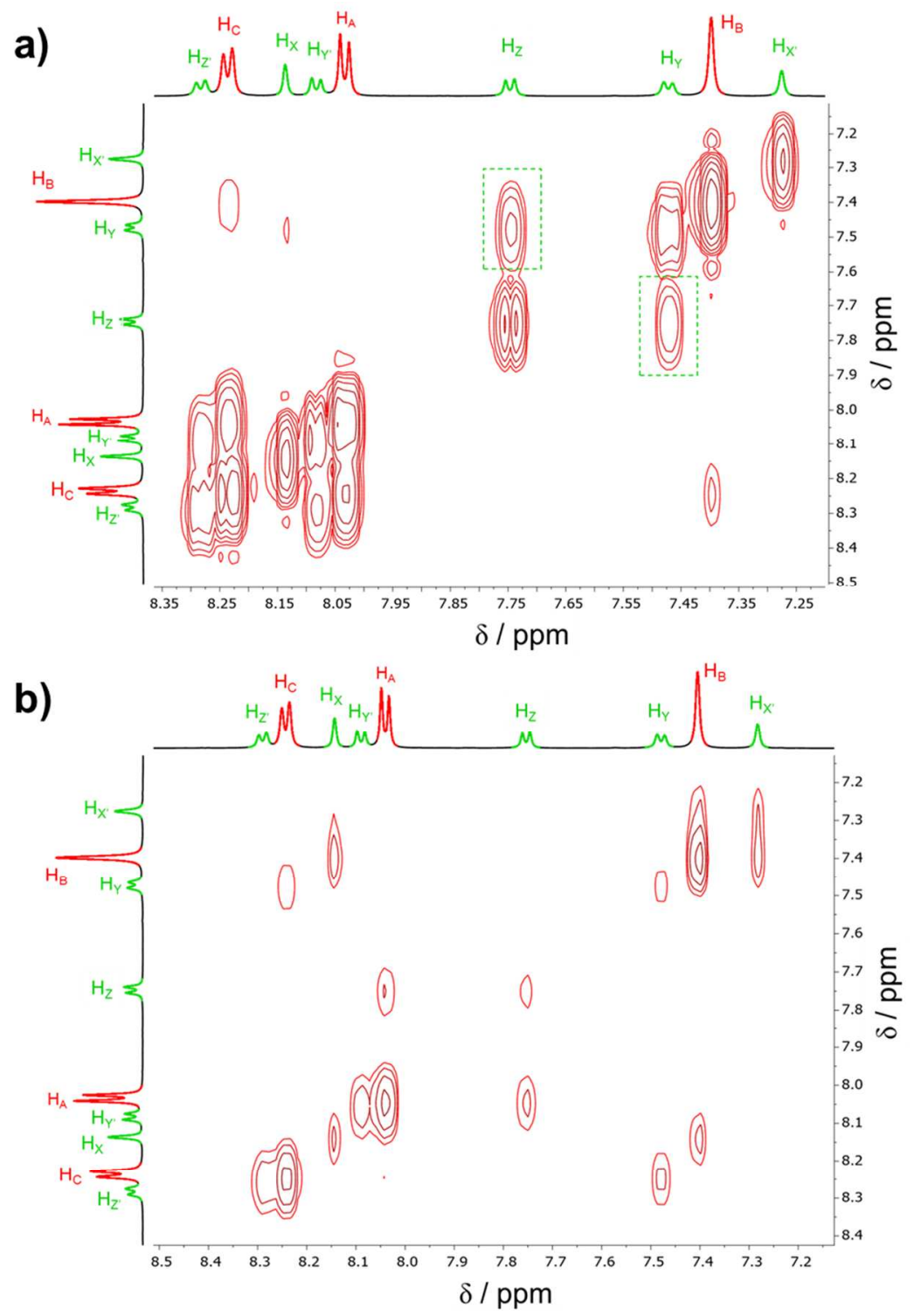

Figure S3. Selected portions of the annotated $2 \mathrm{D}{ }^{1} \mathrm{H}-{ }^{1} \mathrm{H}$ (a) COSY and (b) NOESY NMR spectra (500 MHz, $\mathrm{CD}_{3} \mathrm{SOCD}_{3}, 298 \mathrm{~K}$ ) of $\boldsymbol{R}$-2BTDI 

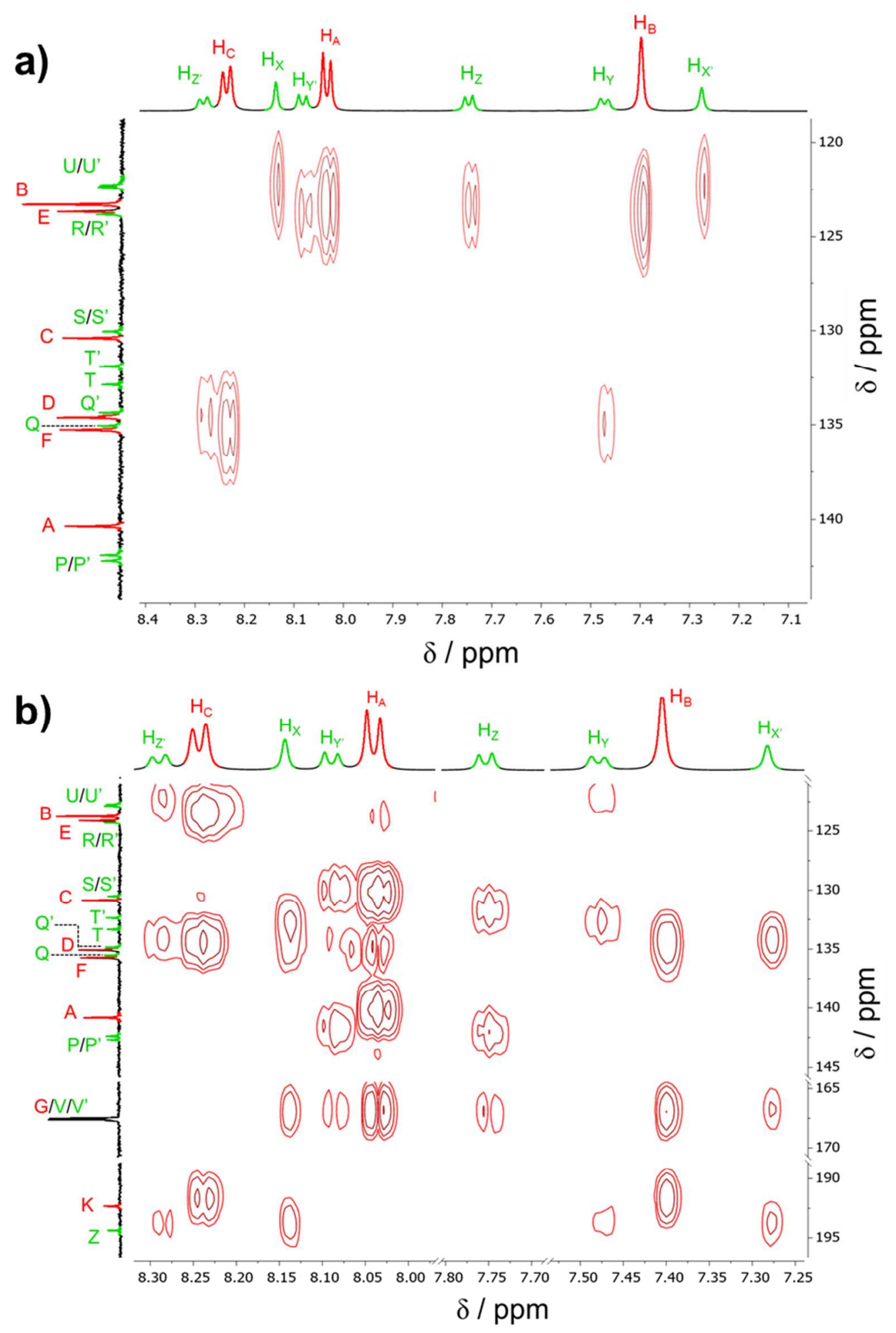

Figure S4. Selected portions of the annotated $2 \mathrm{D}{ }^{1} \mathrm{H}-{ }^{13} \mathrm{C}$ (a) $\mathrm{HSQC}$ and (b) $\mathrm{HMBC}$ spectra $\left(\mathrm{CD}_{3} \mathrm{SOCD}_{3}, 298 \mathrm{~K}\right)$ of $\boldsymbol{R}$-2BTDI 
d)

${ }^{1} \mathrm{H}$ NMR Spectrum of $\mathrm{S}$-2BTDI in $\mathrm{CD}_{3} \mathrm{SOCD}_{3}$

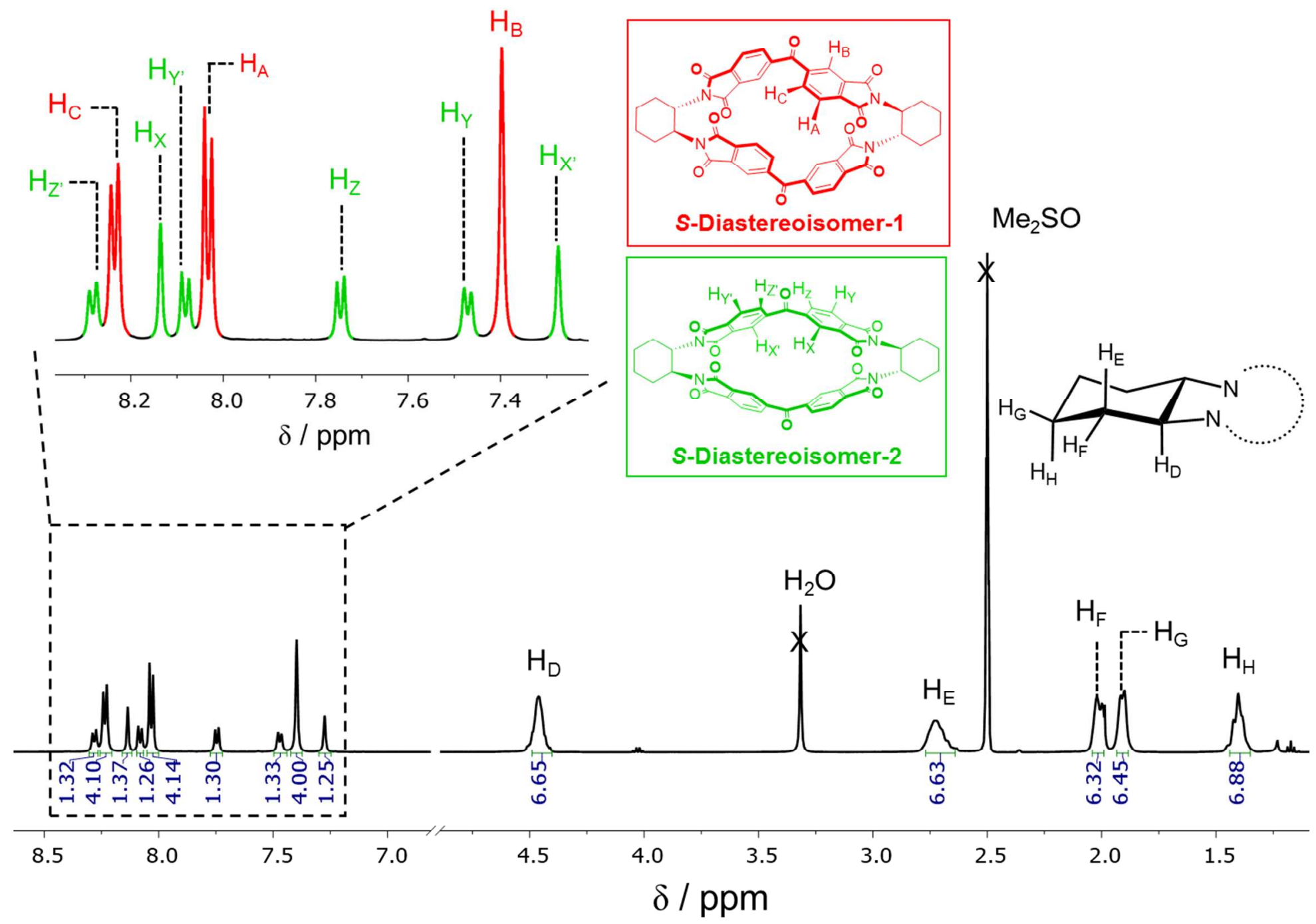

Figure S5. Annotated ${ }^{1} \mathrm{H}$ NMR spectrum $\left(500 \mathrm{MHz}, \mathrm{CD}_{3} \mathrm{SOCD}_{3}, 298 \mathrm{~K}\right)$ of $\boldsymbol{S}$-2BTDI 
e) ${ }^{13} \mathrm{C}$ NMR Spectrum of $S$-2BTDI in $\mathrm{CD}_{3} \mathrm{SOCD}_{3}$
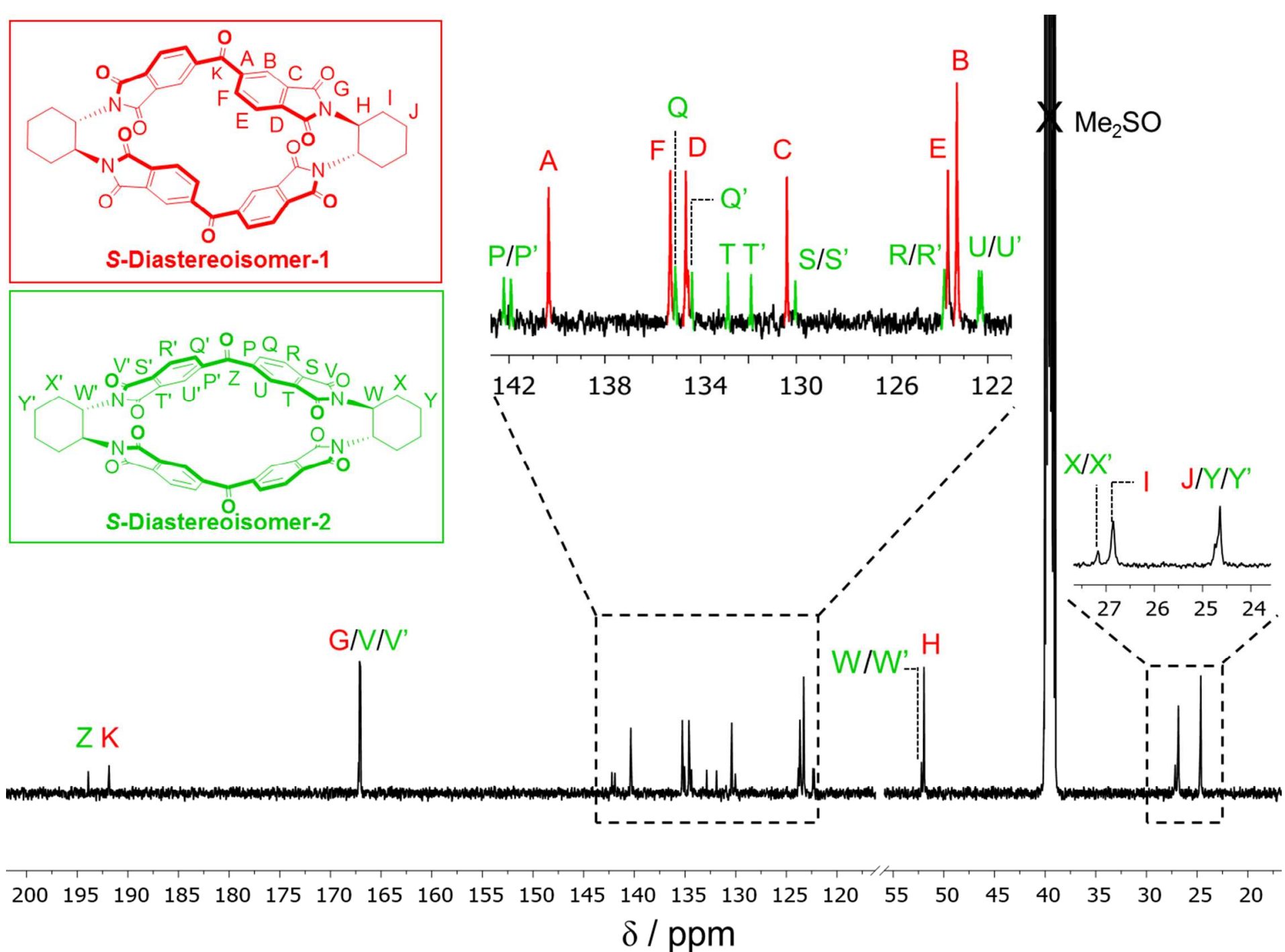

Figure S6. Annotated ${ }^{13} \mathrm{C}$ NMR spectrum $\left(125 \mathrm{MHz}, \mathrm{CD}_{3} \mathrm{SOCD}_{3}, 298 \mathrm{~K}\right)$ of $\boldsymbol{S}$-2BTDI 


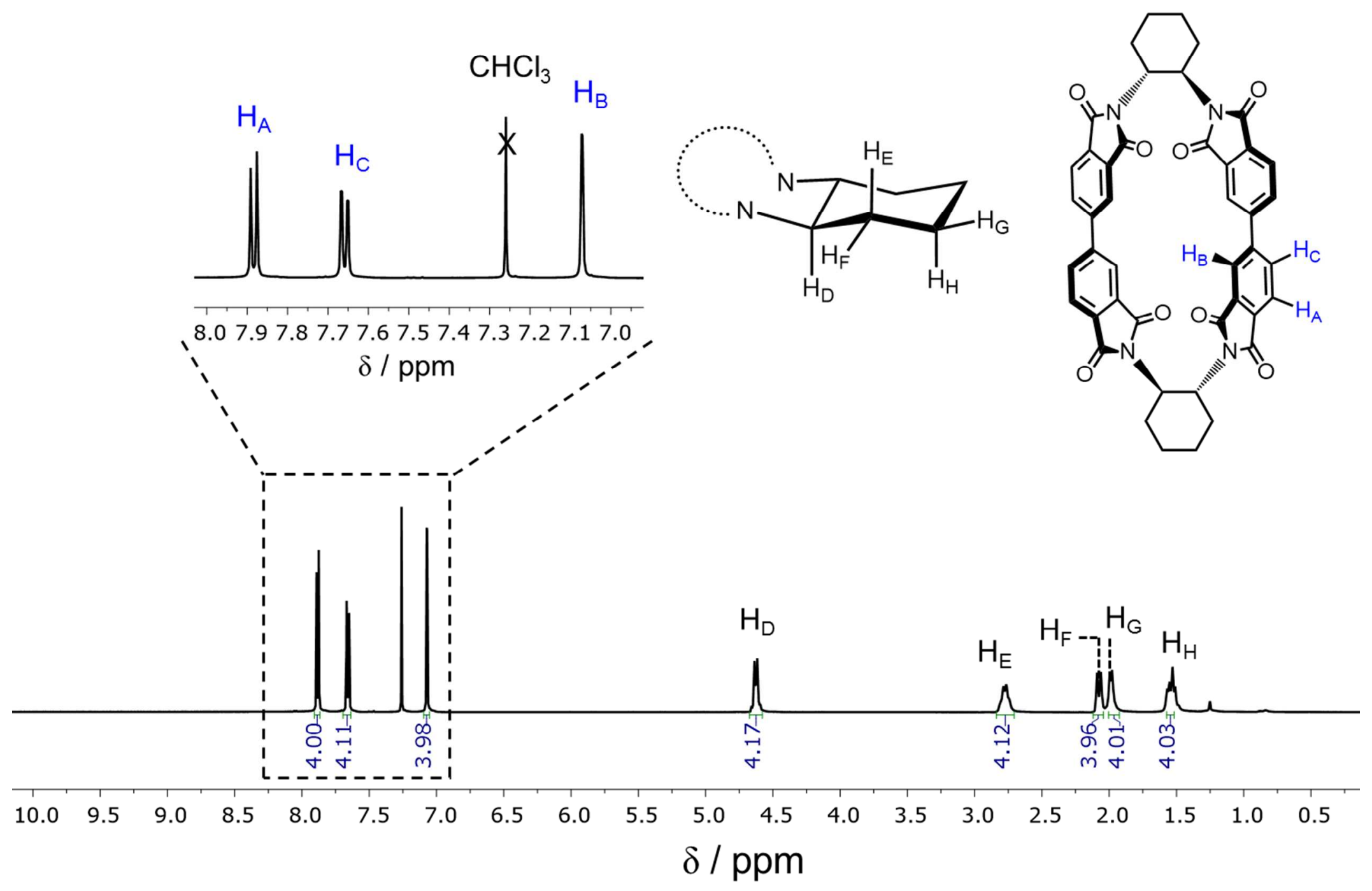

Figure S7. Annotated ${ }^{1} \mathrm{H}$ NMR spectrum ( $500 \mathrm{MHz}, \mathrm{CDCl}_{3}, 298 \mathrm{~K}$ ) of $\boldsymbol{R}$-2BPDI 
g)

${ }^{13} \mathrm{C}$ NMR Spectrum of $\boldsymbol{R}$-2BPDI in $\mathrm{CDCl}_{3}$

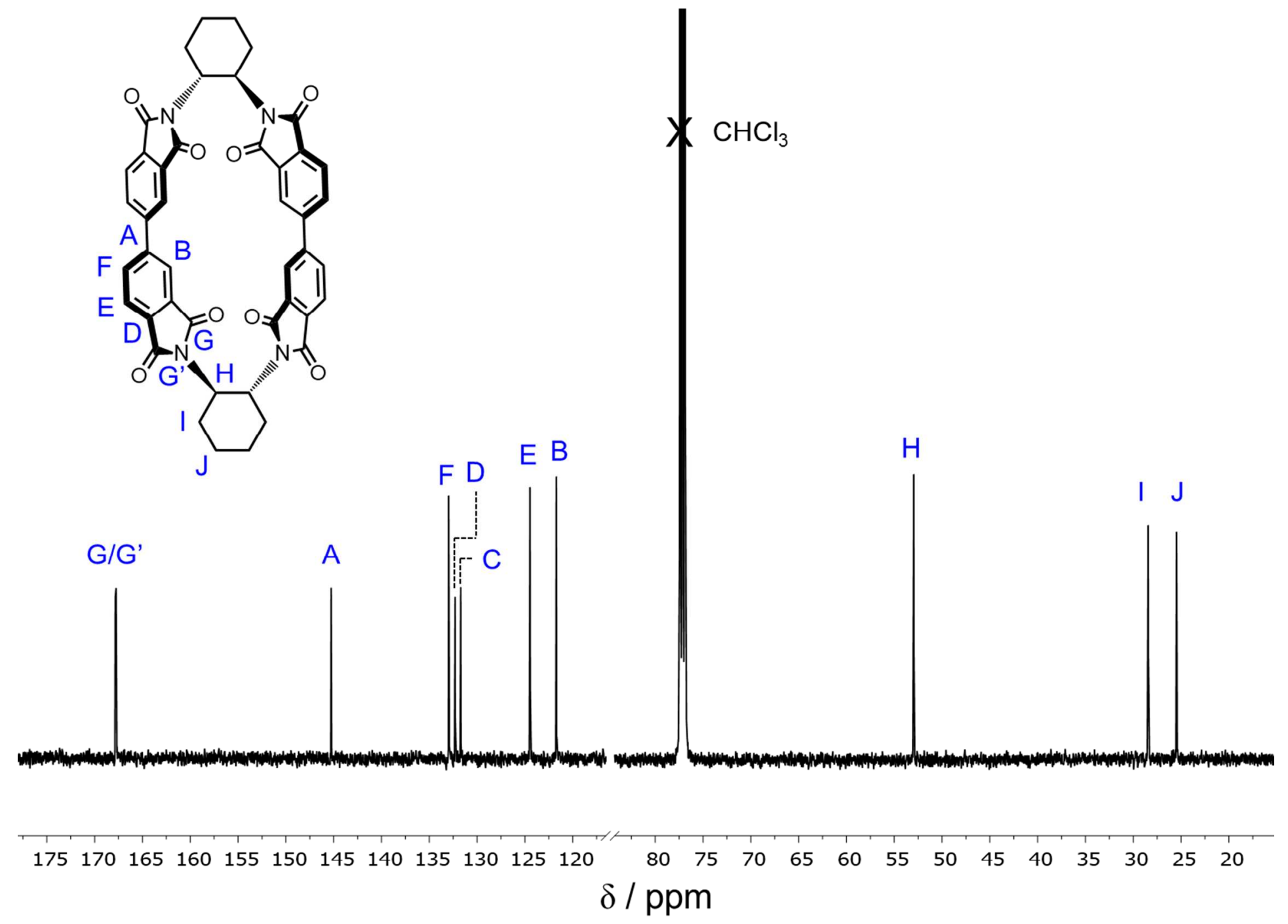

Figure S8. Annotated ${ }^{13} \mathrm{C}$ NMR spectrum $\left(125 \mathrm{MHz}, \mathrm{CDCl}_{3}, 298 \mathrm{~K}\right)$ of $\boldsymbol{R}$-2BPDI 


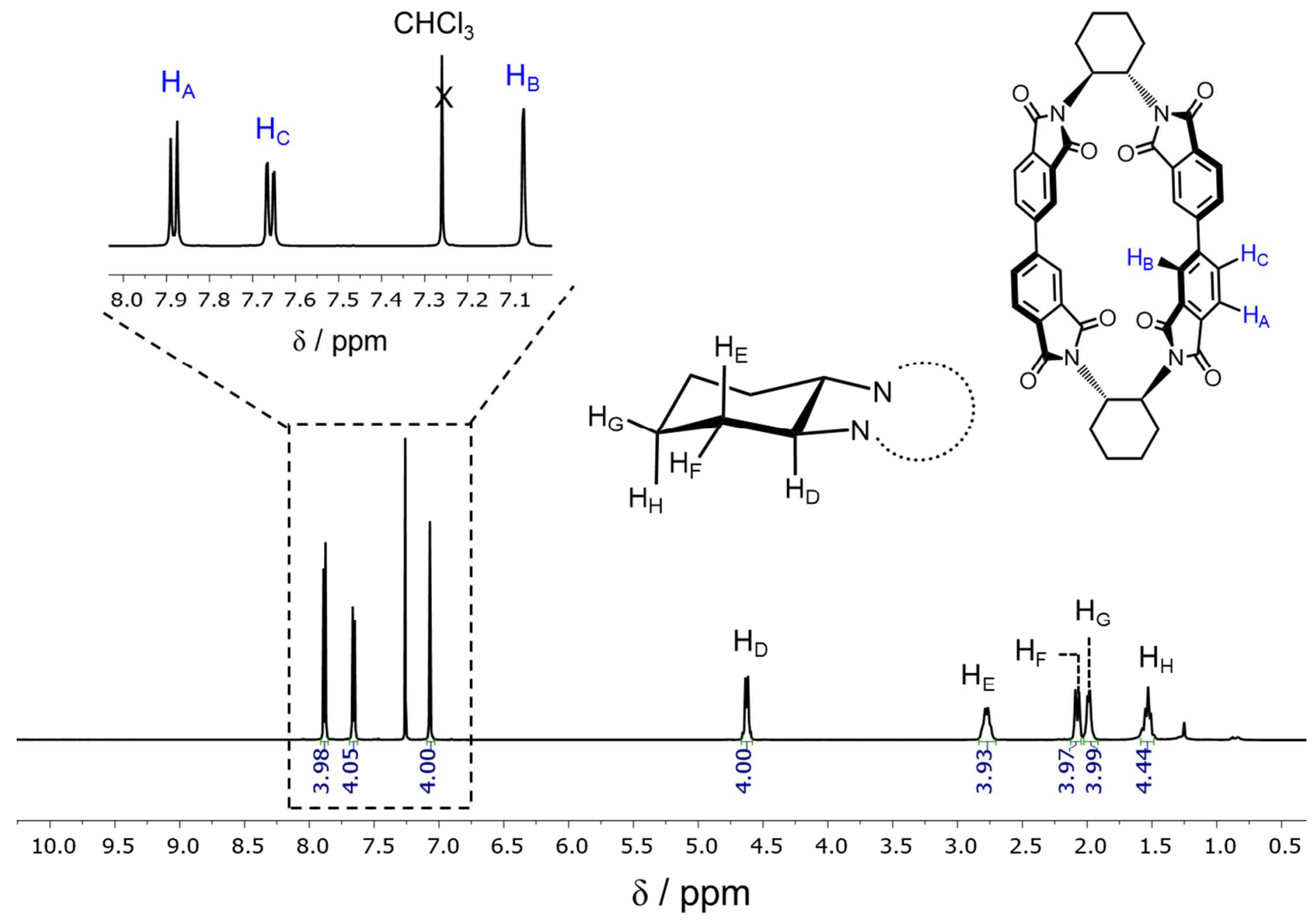

Figure S9. Annotated ${ }^{1} \mathrm{H}$ NMR spectrum (500 MHz, $\mathrm{CDCl}_{3}, 298 \mathrm{~K}$ ) of $\boldsymbol{S}$-2BPDI 

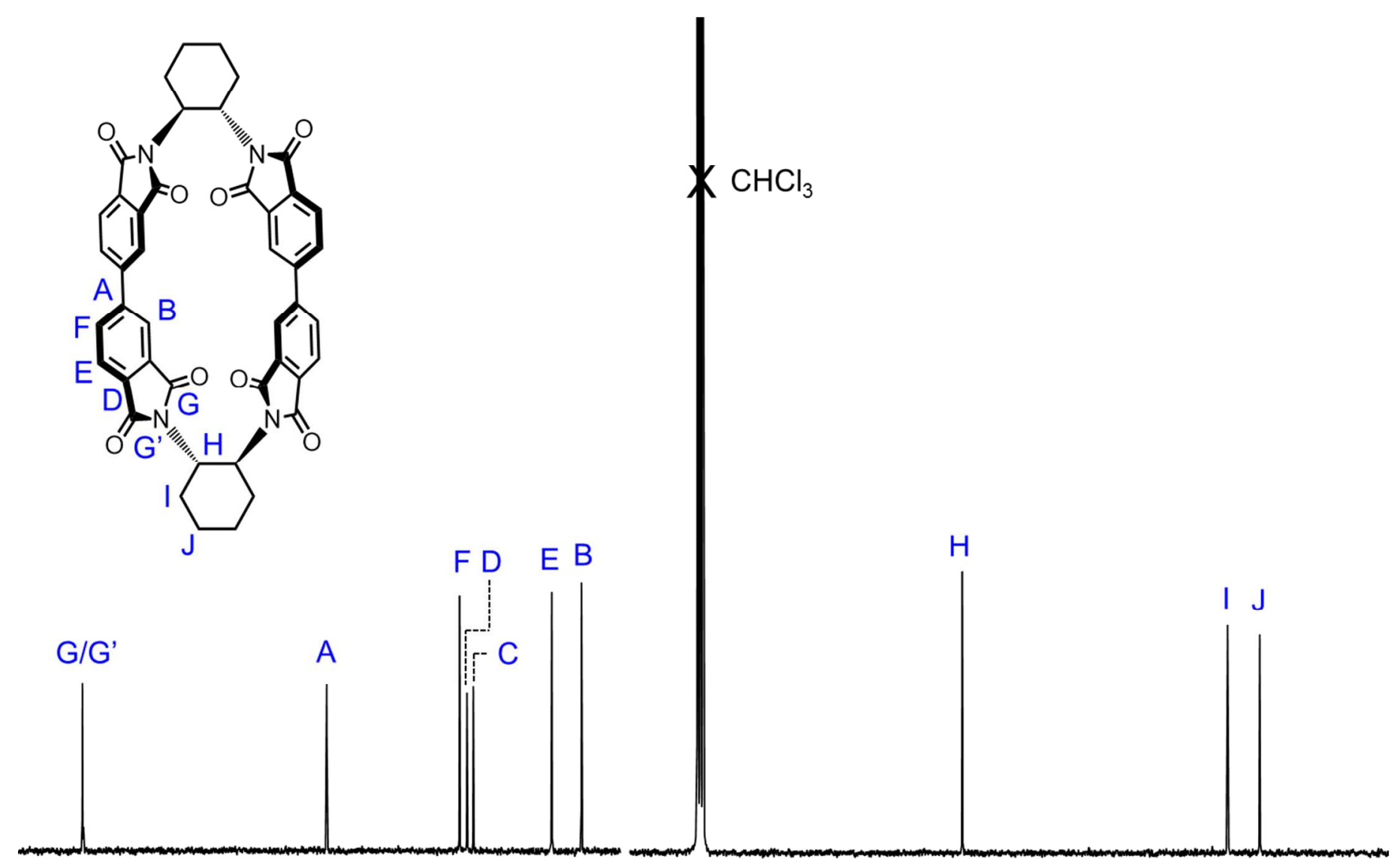

$\begin{array}{lllllllllll}170 & 165 & 160 & 155 & 150 & 145 & 140 & 135 & 130 & 125 & 120\end{array}$

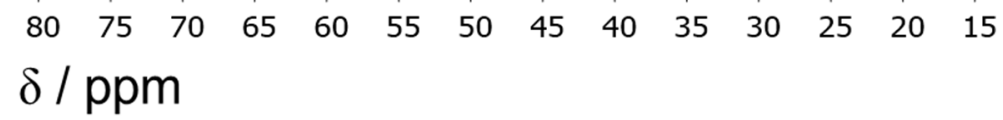

Figure S10. Annotated ${ }^{13} \mathrm{C}$ NMR spectrum (125 MHz, $\left.\mathrm{CDCl}_{3}, 298 \mathrm{~K}\right)$ of $\boldsymbol{S}$-2BPDI 


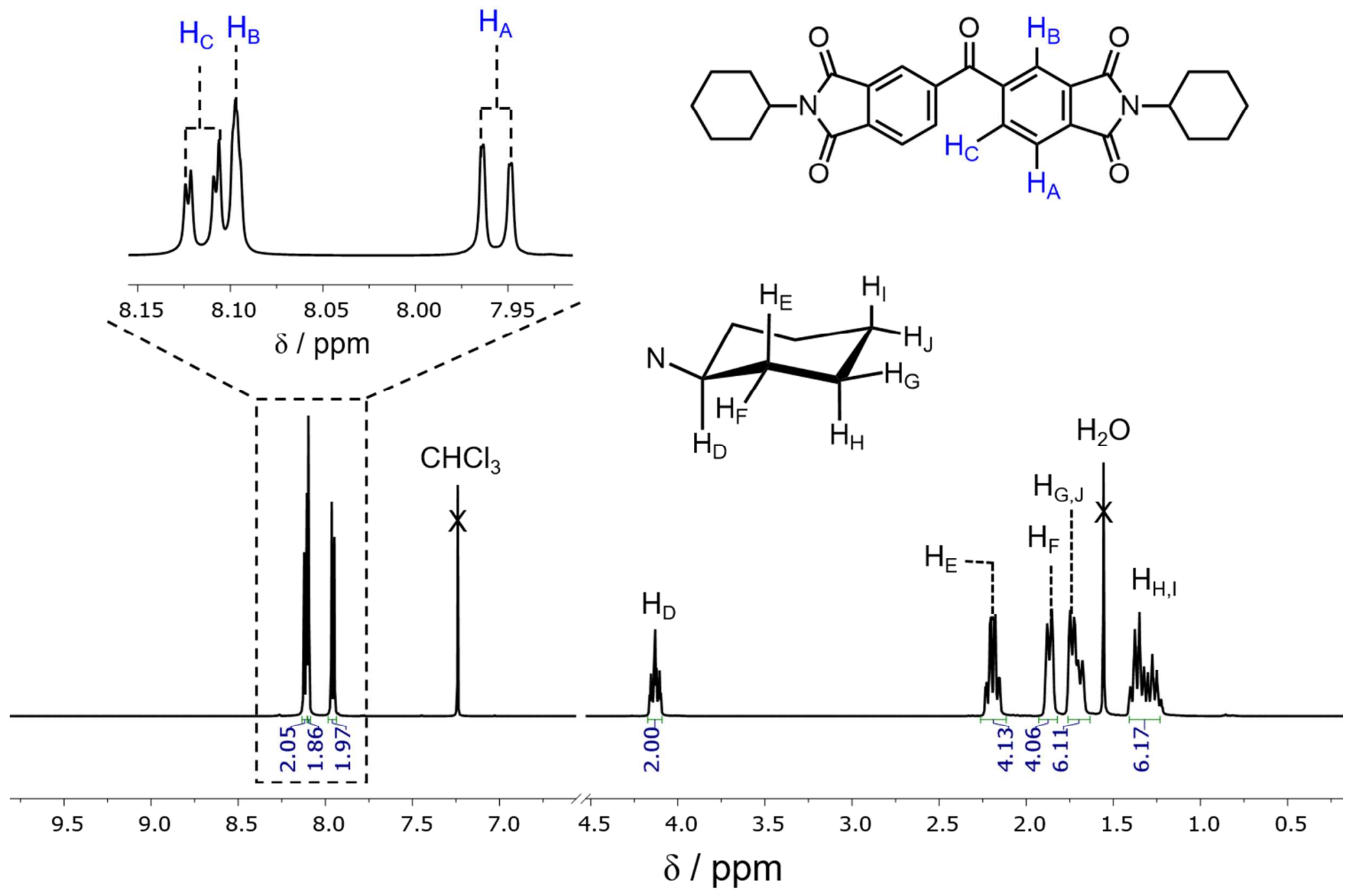

Figure S11. Annotated ${ }^{1} \mathrm{H}$ NMR spectrum (500 MHz, $\mathrm{CDCl}_{3}, 298 \mathrm{~K}$ ) of BTDI-Ref 
k)

${ }^{13} \mathrm{C}$ NMR Spectrum of $2 \mathrm{BTDI}-\mathrm{Ref}$ in $\mathrm{CDCl}_{3}$

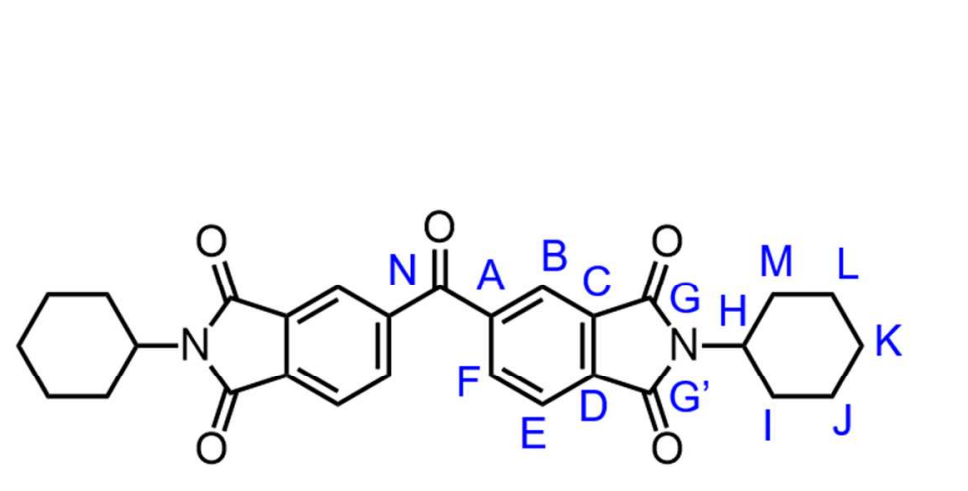

$\mathrm{CHCl}_{3}$
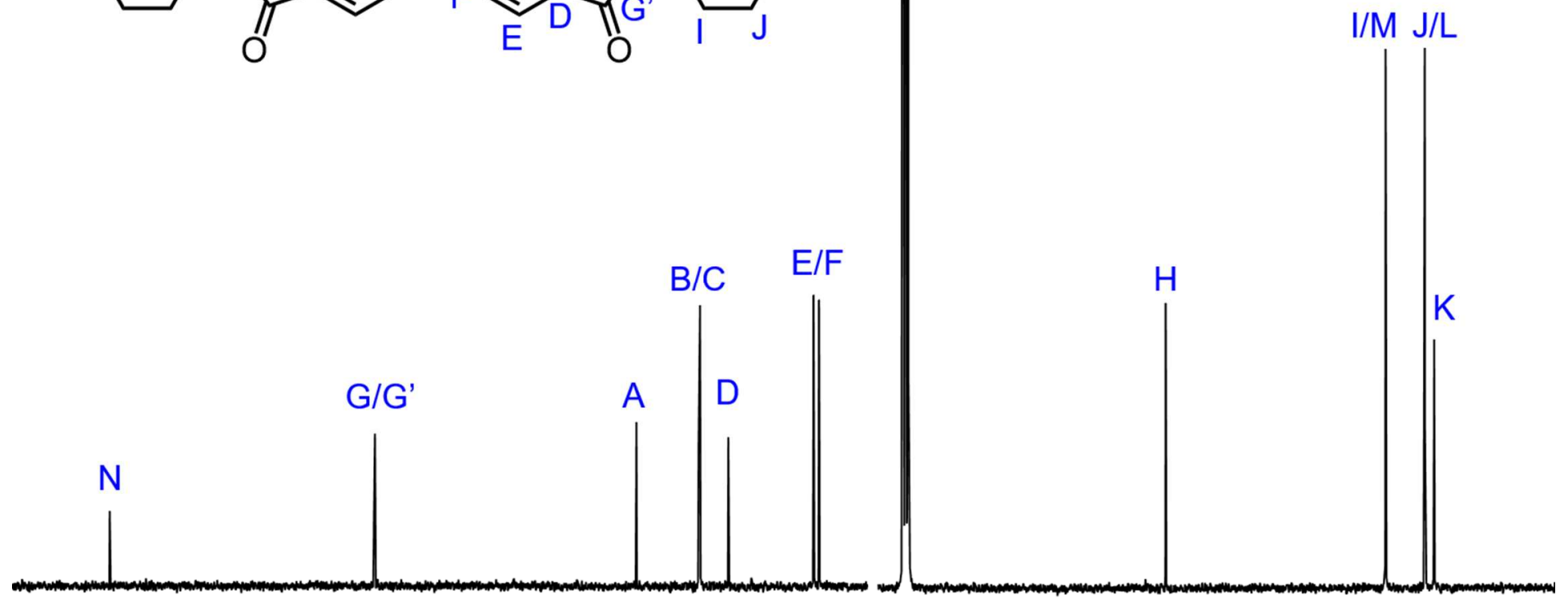

20019

180

170

160

150

140

$\begin{array}{lllllllllllll}75 & 70 & 65 & 60 & 55 & 50 & 45 & 40 & 35 & 30 & 25 & 20 & 15\end{array}$

$\delta / \mathrm{ppm}$

Figure S12. Annotated ${ }^{13} \mathrm{C}$ NMR spectrum (125 MHz, $\mathrm{CDCl}_{3}, 298 \mathrm{~K}$ ) of BTDI-Ref 
${ }^{1} \mathrm{H}$ NMR Spectrum of 2BPDI-Ref in $\mathrm{CDCl}_{3}$

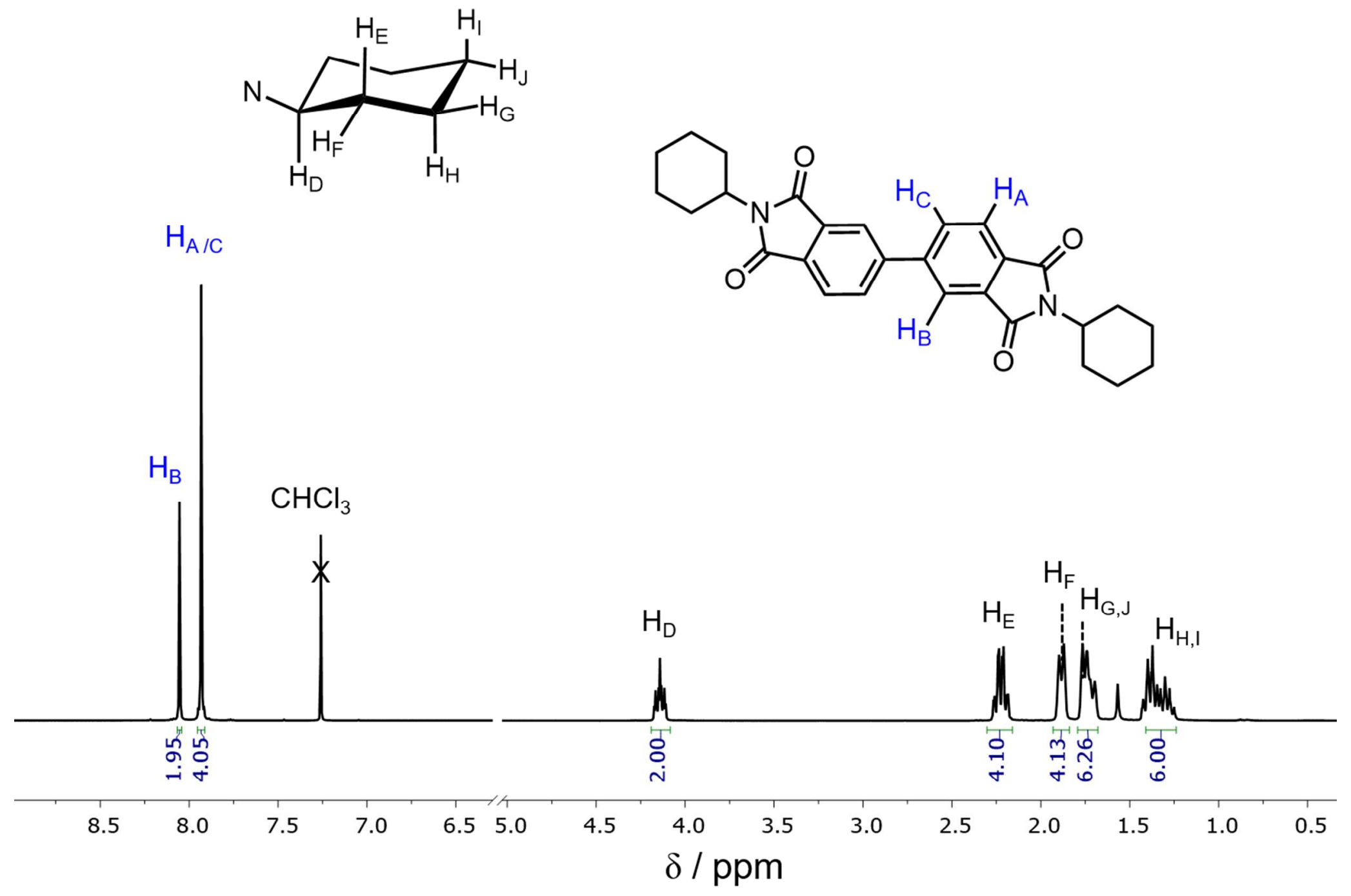

Figure S13. Annotated ${ }^{1} \mathrm{H}$ NMR spectrum ( $500 \mathrm{MHz}, \mathrm{CDCl}_{3}, 298 \mathrm{~K}$ ) of BPDI-Ref 
${ }^{13} \mathrm{C}$ NMR Spectrum of 2BPDI-Ref in $\mathrm{CDCl}_{3}$

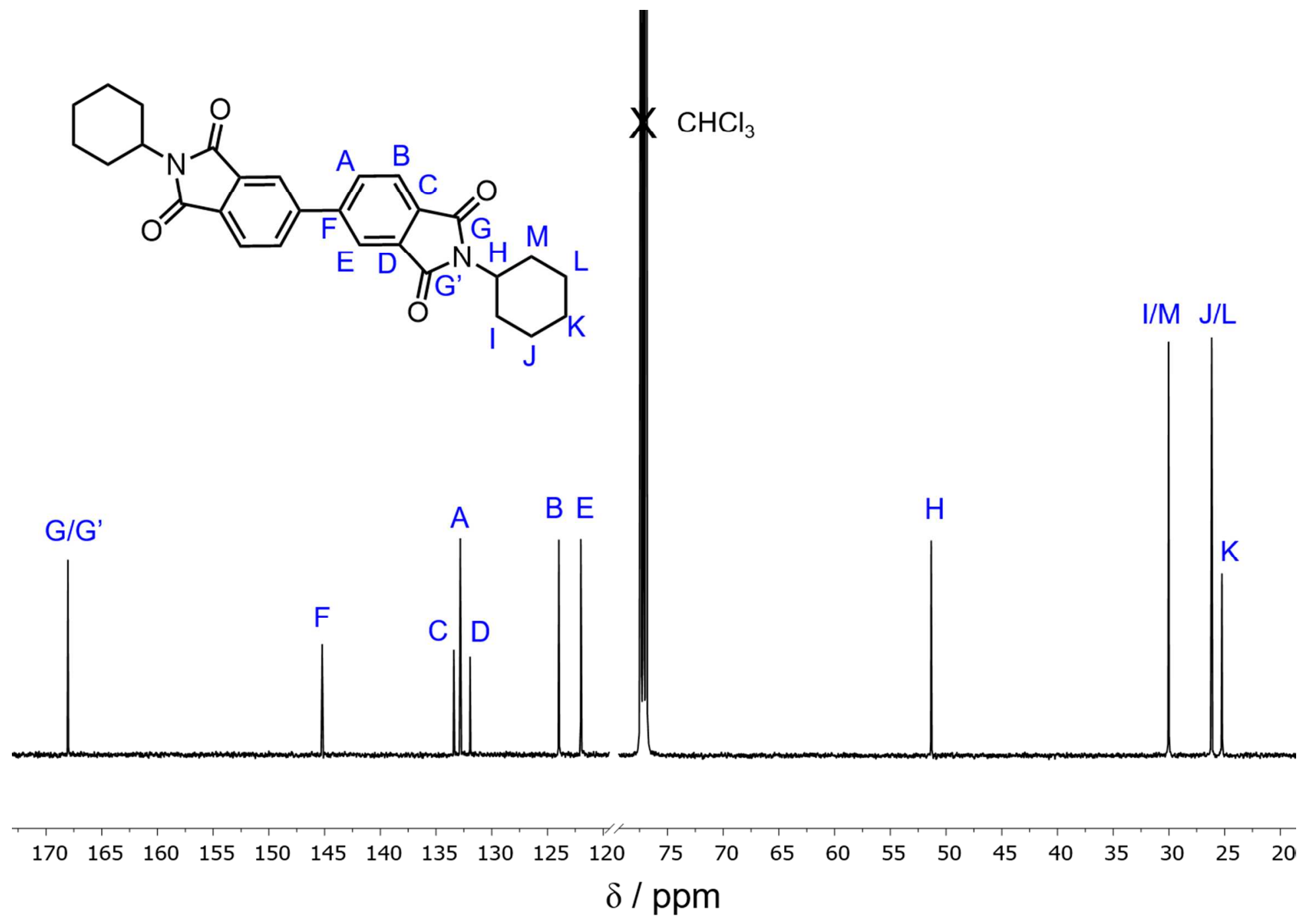

Figure S14. Annotated ${ }^{13} \mathrm{C}$ NMR spectrum $\left(125 \mathrm{MHz}, \mathrm{CDCl}_{3}, 298 \mathrm{~K}\right)$ of BPDI-Ref 


\section{n) Variable Temperature ${ }^{1} \mathrm{H}$ NMR spectra of $\mathrm{R}$-2BTDI in $\mathrm{CD}_{3} \mathrm{SOCD}_{3}$}

Variable temperature (VT) ${ }^{1} \mathrm{H}$ NMR spectra were recorded in order to assess the rate of the equilibration between the two diastereoisomeric co-conformations. At room temperature, since the exchange rates of two diastereoisomers is slower than that of the ${ }^{1} \mathrm{H}$ NMR timescale, the resonances separate into two sets of distinct signals (Figure S15). As the temperature was raised two sets of signals coalescence into one set of signals indicating the rapid conversion between two diastereoisomers. The methine protons on the cyclohexano moieties remain unchanged at the elevated temperature.

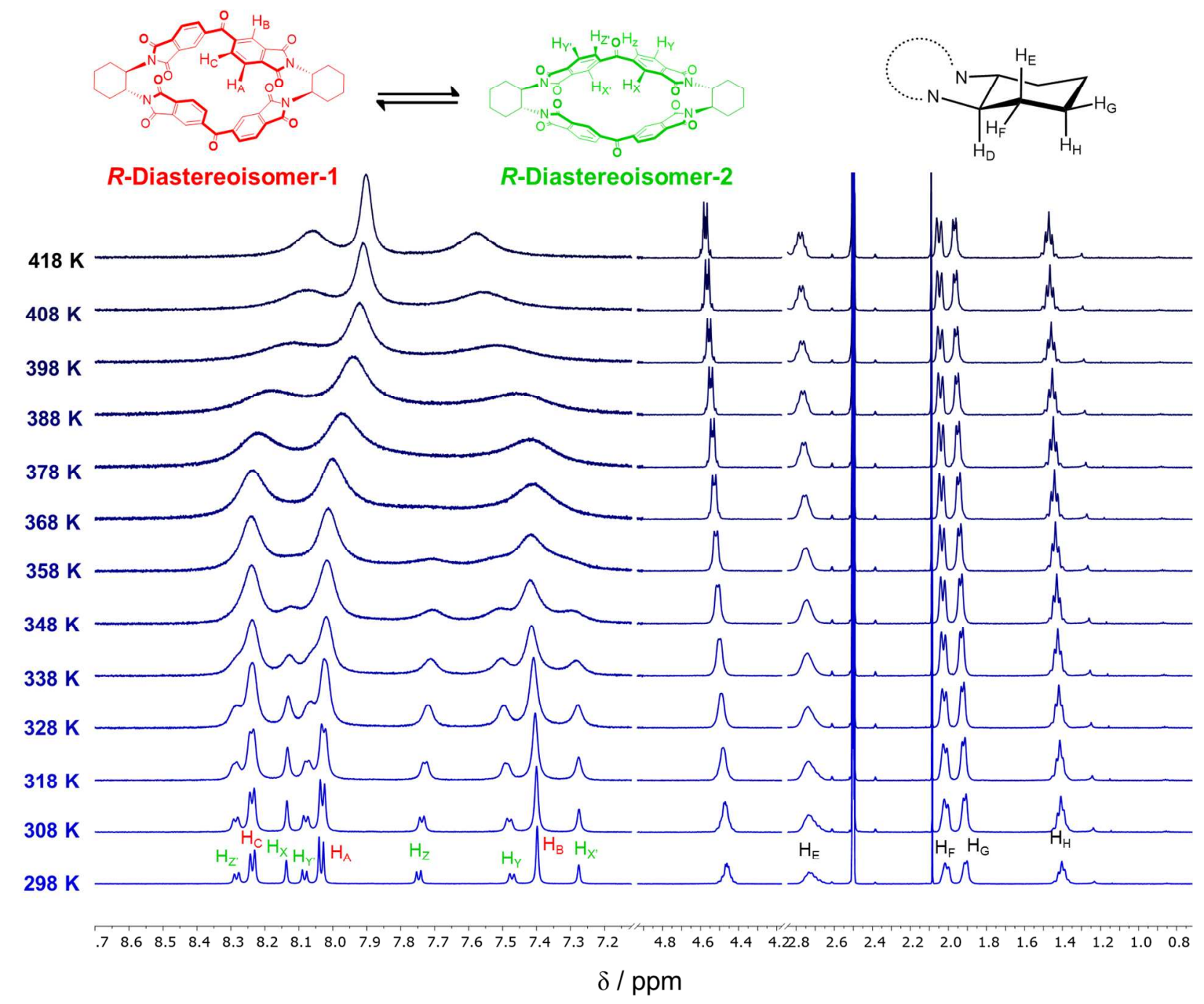

Figure S15. Variable temperature ${ }^{1} \mathrm{H}$ NMR spectra $\left(600 \mathrm{MHz}, \mathrm{CD}_{3} \mathrm{SOCD}_{3}\right)$ recorded in the aromatic region of $\boldsymbol{R}$-2BTDI: The coalescence temperature for $\boldsymbol{R}$-Diastereoisomer-1 and $\boldsymbol{R}$ Diastereoisomer-2 protons $\left[\left(\mathrm{H}_{\mathrm{C}}, \mathrm{H}_{\mathrm{Z}^{\prime}}\right.\right.$ and $\left.\mathrm{H}_{\mathrm{Z}}\right)$ or $\left(\mathrm{H}_{\mathrm{A}}, \mathrm{H}_{\mathrm{Y}^{\prime}}\right.$ and $\left.\mathrm{H}_{\mathrm{Y}}\right)$ or $\left(\mathrm{H}_{\mathrm{X}}, \mathrm{H}_{\mathrm{B}}\right.$ and $\left.\left.\mathrm{H}_{\mathrm{X}^{\prime}}\right)\right]$ is observed at $378 \mathrm{~K}$. 


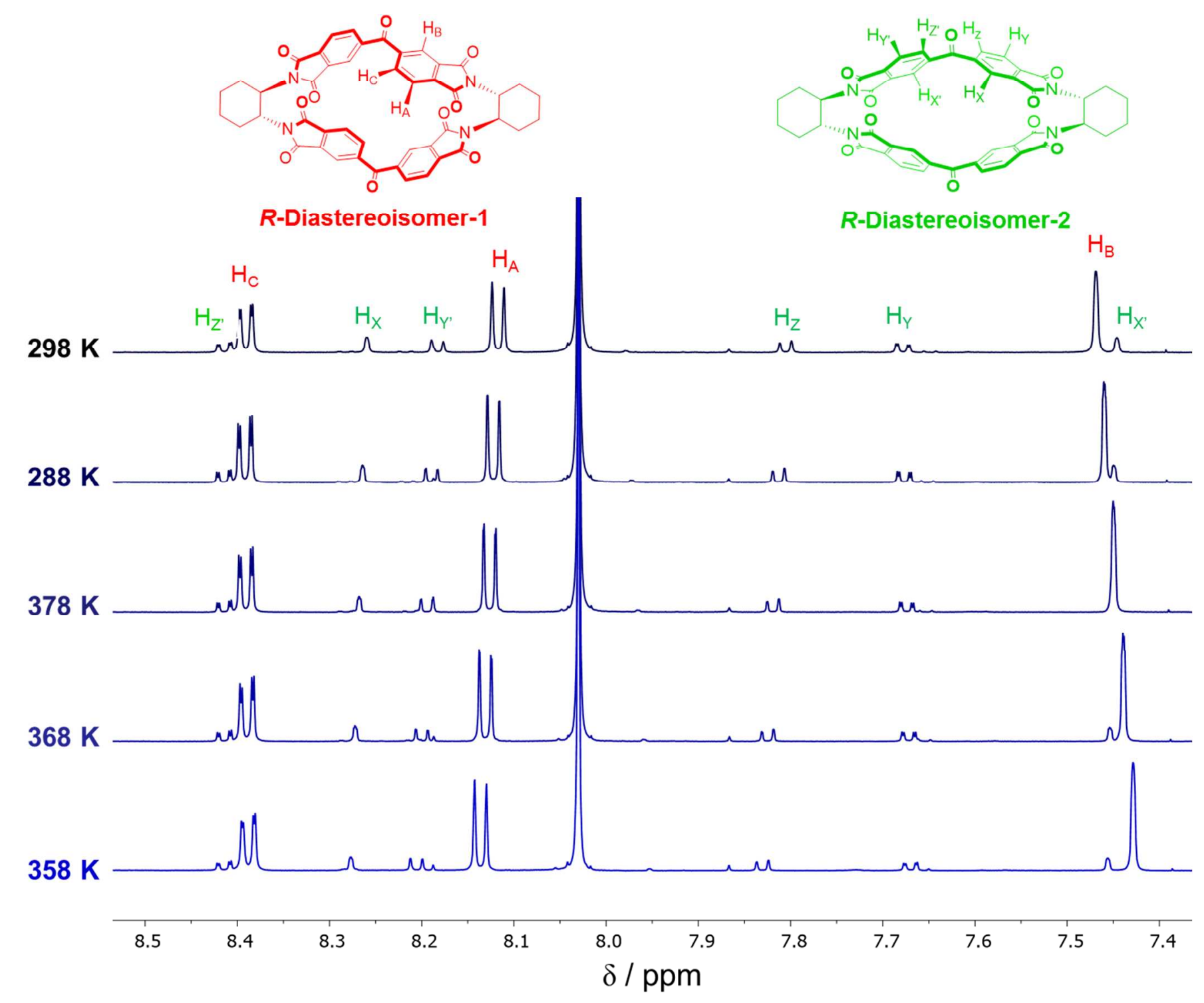

Figure S16. Variable temperature ${ }^{1} \mathrm{H}$ NMR spectra $(600 \mathrm{MHz}, \mathrm{DMF})$ in the aromatic region of $\boldsymbol{R}$-2BTDI. 


\section{o) Variable Temperature ${ }^{1} \mathrm{H}$ NMR spectra of $R$-2BPDI in DMF}

The VT ${ }^{1} \mathrm{H}$ NMR spectra of $\boldsymbol{R}$-2BPDI (Figure S16) does not show any coalescence or broadening of signals even at $418 \mathrm{~K}$, presumably because of the rigidity in the BPDI units, leading to the nonexistence of interconvertible conformational diastereoisomers on the ${ }^{1} \mathrm{H}$ NMR timescale.
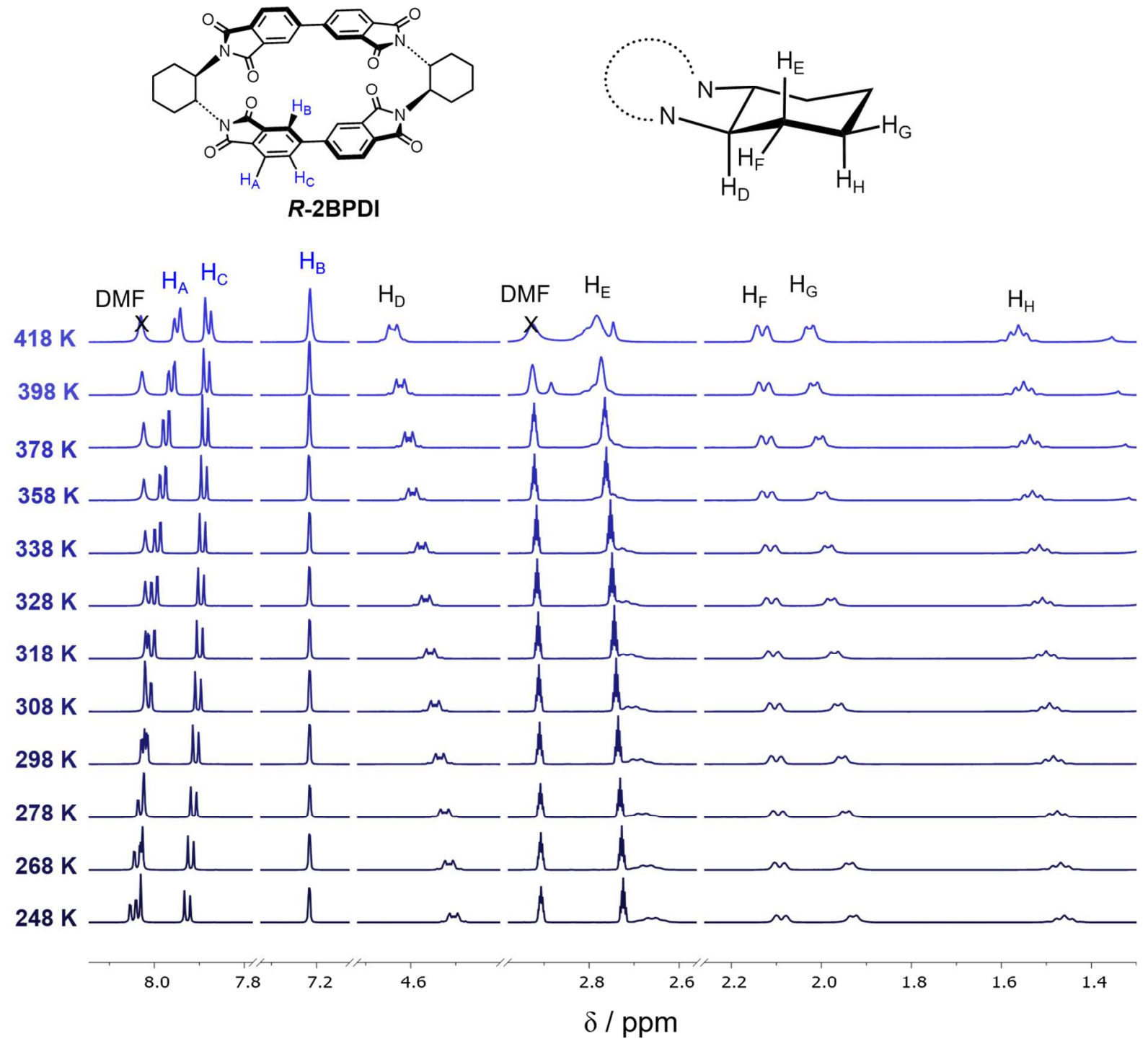

Figure S17. Variable temperature ${ }^{1} \mathrm{H}$ NMR spectra $\left(600 \mathrm{MHz}, \mathrm{DMF}-d_{7}\right)$ in the aromatic region of $\boldsymbol{R}$-2BPDI: no coalescence of signals is observed. 


\section{Section D. Variable-Temperature CD (VT CD) of R-2BPDI}

There was no isosbestic point or change in intensity of CD signal observed in the case of VT CD of $\boldsymbol{R}$-2BPDI demonstrating clearly the existence of a single conformational diastereisomer in solution.

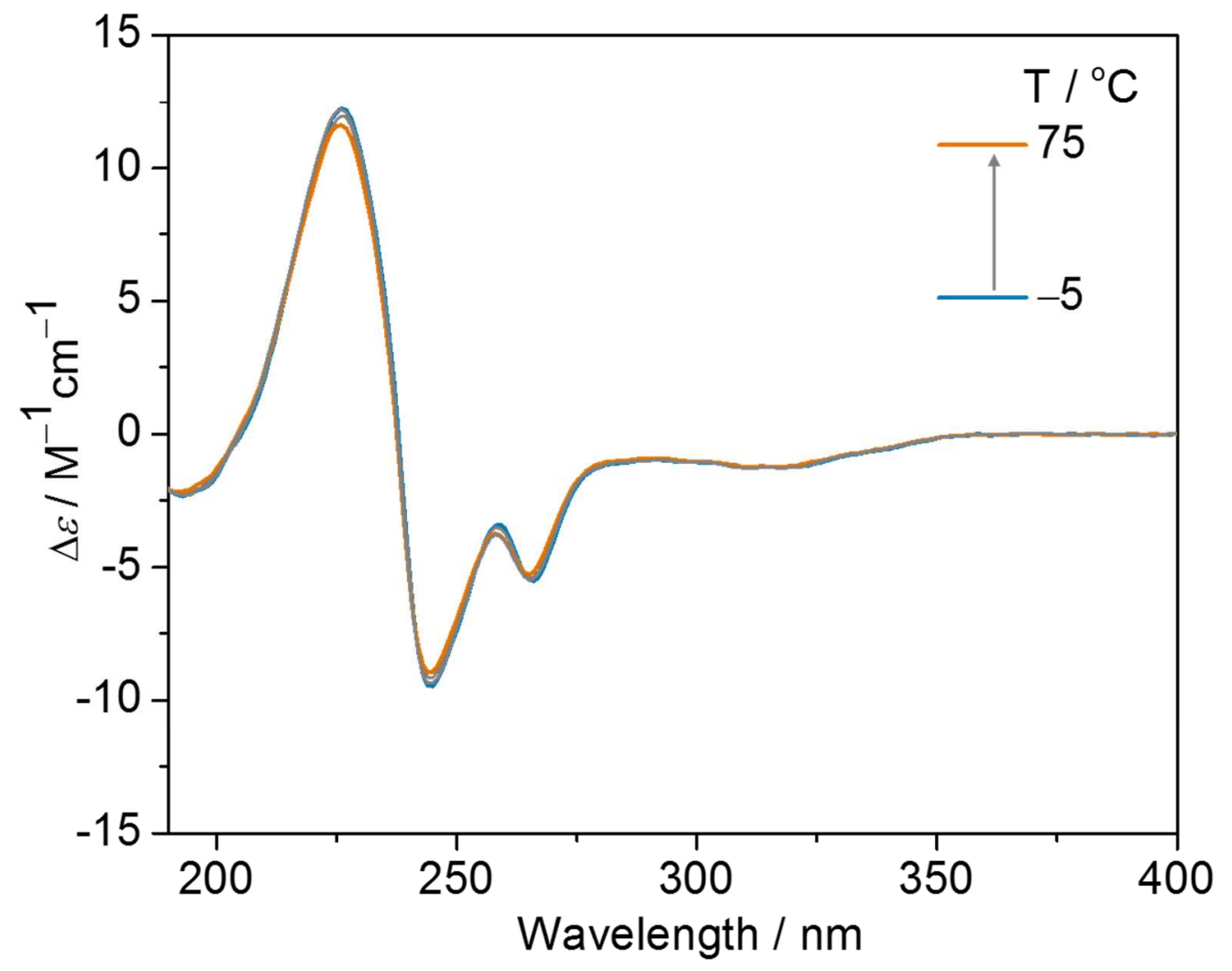

Figure S18. Variable-temperature CD spectra of $\boldsymbol{R}-\mathbf{2 B P D I}$ in $\mathrm{MeCN}$. 


\section{Section E. Crystallographic Characterization}

\section{a) $R$-2BTDI}

1) Method: Single crystals of $\boldsymbol{R}$-2BTDI were grown by slow vapor diffusion of $n$-hexane into a $4.0 \mathrm{mM}$ solution of the macrocycle in 1,2-dichloroethane over the course of 7 days at $4{ }^{\circ} \mathrm{C}$. A suitable crystal was selected and mounted in inert oil and transferred to the cold gas stream of Kappa Apex 2 diffractometer. The crystal was kept at $99.99 \mathrm{~K}$ during data collection. Using Olex $2^{\mathrm{S} 2}$, the structure was solved with the $\mathrm{ShelXT}^{\mathrm{S} 3}$ structure solution program using Direct Methods and refined with the ShelXL ${ }^{\mathrm{S} 4}$ refinement package using Least Squares minimization.

2) Crystal Data: Tetragonal, space group $P 4122$ (no. 91), $a=15.4764(5), c=40.5896(19) \AA, V=$ $9722.0(8) \AA^{3}, Z=8, T=99.99 \mathrm{~K}, \mu\left(\mathrm{Cu}_{\mathrm{K} \alpha}\right)=1.691 \mathrm{~mm}^{-1}, D_{\text {calc }}=1.229 \mathrm{~g} / \mathrm{mm}^{3}, 17999$ reflections measured $(5.71 \leq 2 \theta \leq 100.872), 5096$ unique $\left(R_{\text {int }}=0.0960, R_{\text {sigma }}=0.0923\right)$ which were used in all calculations. The final $R_{1}$ was $0.0768(\mathrm{I}>2 \sigma(\mathrm{I}))$ and $w R_{2}$ was 0.2251 (all data).

3) Refinement Details: The enhanced rigid-bond restraint (SHELX keyword RIGU) was applied globally. Distance restraints were imposed on the $\mathrm{Cl}-\mathrm{C}$ bonds.

4) Solvent Treatment Details: The solvent masking procedure as implemented in Olex 2 was used to remove the electronic contribution of solvent molecules from the refinement. As the exact solvent content is not known, only the atoms used in the refinement model are reported in the formula here. Total solvent accessible volume / cell $=1994.7 \AA^{3}[20.5 \%]$ Total electron count / cell $=500.3$.

\section{b) $S$-2BTDI}

1) Method: Single colorless needle-shaped crystals of $\boldsymbol{S}$-2BTDI were obtained by slow vapor diffusion of $n$-hexane into a $4.0 \mathrm{mM}$ solution of the macrocycle in 1,2-dichloroethane over the course of 7 days at $4{ }^{\circ} \mathrm{C}$. The crystal was chosen from the sample as supplied. A suitable crystal $(0.21 \times 0.03 \times 0.02 \mathrm{~mm})$ was selected and mounted on a glass fibre in Paratone oil on a Bruker 
Kappa APEX CCD area detector diffractometer. The crystal was kept at $T=100(2) \mathrm{K}$ during data collection. Using Olex $2^{2}$, the structure was solved with the $\mathrm{XM}^{4}$ structure solution program, using the Dual Space solution method. The model was refined with version 2014-3 of XL using Least Squares minimization.

2) Crystal Data: $\mathrm{C}_{47} \mathrm{H}_{34} \mathrm{ClN}_{4} \mathrm{O}_{10}, M_{r}=850.23$, tetragonal, $P 4_{3} 22$ (No. 95), $a=15.4749(5), c=$ 40.5132(15) $\AA, V=9701.8(7) \AA^{3}, T=100(2) \mathrm{K}, Z=8, Z^{\prime}=1, \mu\left(\mathrm{Cu}_{\mathrm{K} \alpha}\right)=1.173,32085$ reflections measured, 5113 unique $\left(R_{\text {int }}=0.0913\right)$ which were used in all calculations. The final $w R_{2}$ was 0.2880 (all data) and $R_{1}$ was $0.0918(\mathrm{I}>2 \sigma(\mathrm{I})$ ).

3) Solvent Treatment Details: The solvent masking procedure as implemented in Olex 2 was used to remove the electronic contribution of solvent molecules from the refinement. As the exact solvent content is not known, only the atoms used in the refinement model are reported in the formula here. Total solvent accessible volume / cell $=2442.6 \AA[25.2 \%]$ Total electron count / cell $=727.8$

\section{c) $R$-2BPDI}

1) Method: Single crystals of $\boldsymbol{R}$-2BPDI were grown by slow vapor diffusion of $\mathrm{MeOH}$ into a $4.0 \mathrm{mM}$ solution of the macrocycle in $\mathrm{CHCl}_{3}$ over the course of 7 days at $4{ }^{\circ} \mathrm{C}$. A suitable crystal was selected and mounted in inert oil and transferred to the cold gas stream of a Kappa Apex 2 diffractometer. The crystal was kept at $99.99 \mathrm{~K}$ during data collection. Using Olex $2^{2}$, the structure was solved with the ShelXT ${ }^{3}$ structure solution program using Direct Methods and refined with the ShelXL ${ }^{4}$ refinement package using Least Squares minimization.

2) Crystal Data: Monoclinic, space group $C 2$ (no. 5), $a=32.045(4), b=8.2580(9), c=$ 14.0706(15) $\AA, \beta=97.500(3)^{\circ}, V=3691.6(7) \AA^{3}, Z=4, T=99.99 \mathrm{~K}, \mu\left(\mathrm{Cu}_{\mathrm{K} \alpha}\right)=0.812 \mathrm{~mm}^{-1}$, $D_{\text {calc }}=1.398 \mathrm{~g} / \mathrm{mm}^{3}, 19174$ reflections measured $(6.336 \leq 2 \theta \leq 130.358), 6201$ unique $\left(R_{\mathrm{int}}=0.0377, R_{\text {sigma }}=0.0421\right)$ which were used in all calculations. The final $R_{1}$ was 0.0372 (I $>$ $2 \sigma(\mathrm{I}))$ and $w R_{2}$ was 0.1008 (all data). 


\section{Section F. Density Function Theory (DFT) Structure Optimization}

Density functional theory (DFT) calculations were carried out using Q-Chem ${ }^{\mathrm{S} 5}$, version number 4.2.0. The Perdew-Burke-Ernzerhof ${ }^{\mathrm{S} 6}$ (PBE) type of GGA exchange- correlation functional was applied for geometry optimizations with the $6-311 \mathrm{G}^{* *}$ basis set. The van der Waals correction was taken into account using Grimme's empirical dispersion potential. ${ }^{\mathrm{S} 7}$ The solvent is taken into account via CPCM model. ${ }^{\mathrm{S} 8}$

\section{a) $R$-Diastereoisomer-1}
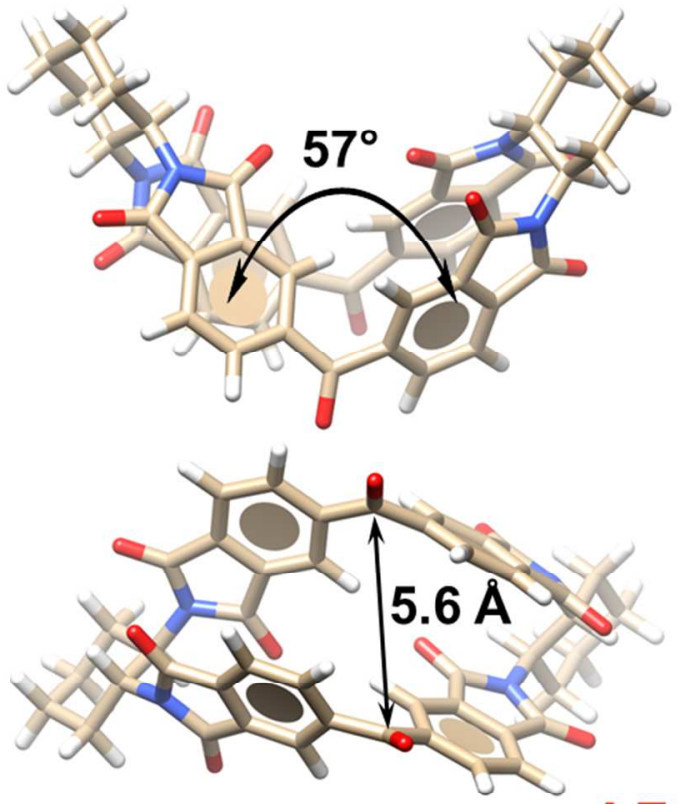

\section{Energy}

$\mathrm{kcal} \mathrm{mol}^{-1}-1726983.255$

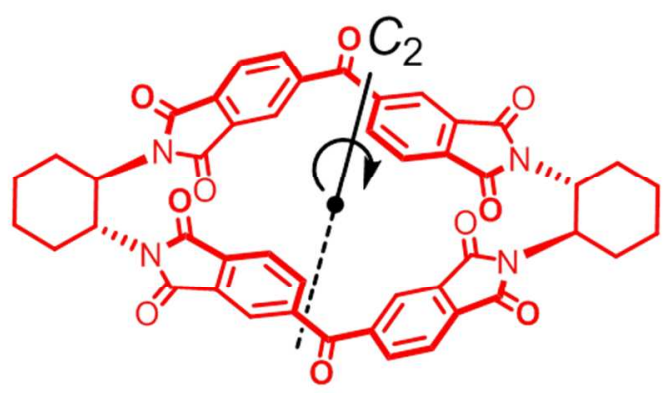

\section{b) R-Diastereoisomer-2}
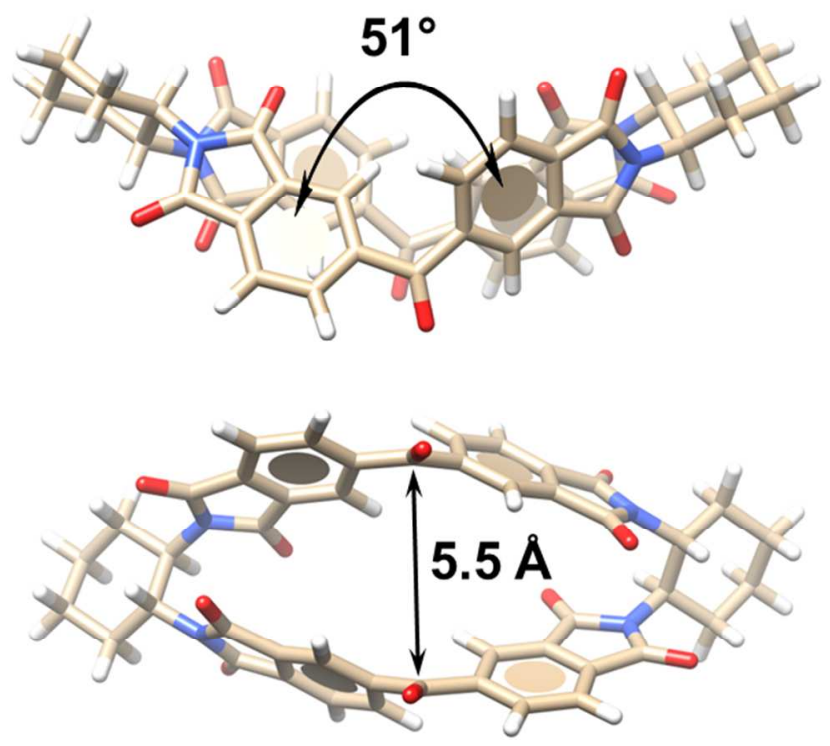

$\Delta E=0.25 \mathrm{kcal} \mathrm{mol}^{-1}$

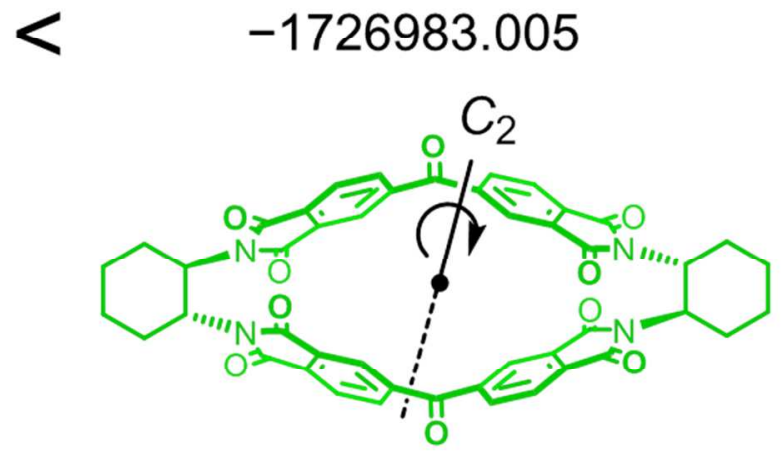

Figure S19. DFT-optimized structures of $\boldsymbol{R}$-Diastereoisomer-1 (a) and $\boldsymbol{R}$-Diastereoisomer-2 (b) of $\boldsymbol{R}$-2BTDI. C, tan; H, white; O, red; N, blue. 
Table S1. Comparison of Torsion Angles for Two Conformational Diastereoisomers $\boldsymbol{R}$-Diastereoisomer-1 and $\boldsymbol{R}$ Diastereoisomer-2 of $\boldsymbol{R}$-2BTDI with Benzophenone

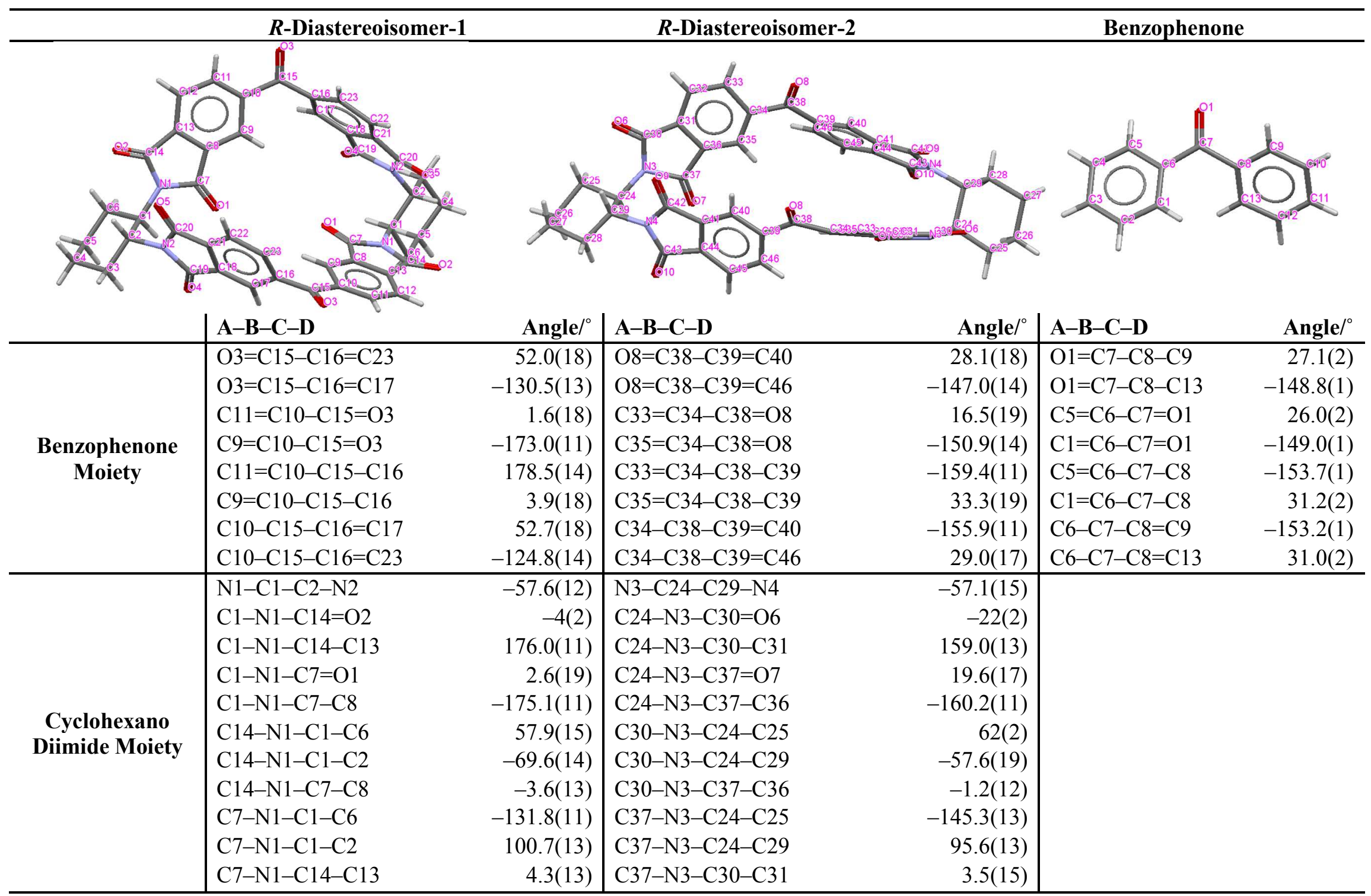


Table S2. Comparison Between the Double Helix of DNA and the Double Helices in This Work.

\begin{tabular}{|c|c|c|}
\hline Building Blocks & $\begin{array}{l}\text { Two Complementary } \\
\text { Polynucleotide Strands }\end{array}$ & $\begin{array}{l}\text { Two Complementary Supramolecular Single-Handed Helices } \\
\text { Consisted of conformational Diastereoisomer-1 and } \\
\text { Diastereoisomer-2, respectively }\end{array}$ \\
\hline One Helical Pitch & $\begin{array}{l}\text { 10.4 Complementary Base Pairs } \\
\text { (B-DNA) }\end{array}$ & $\begin{array}{l}\text { Four Complementary Pairs of conformational } \\
\text { Diastereoisomer-1 and Diastereoisomer-2 }\end{array}$ \\
\hline Helical Sense & $\begin{array}{l}\text { Right-Handed: A-DNA and B-DNA } \\
\text { Left-Handed: Z-DNA }\end{array}$ & $\begin{array}{l}R \text {-2BTDI } \rightarrow \text { Right-Handed } \\
\text { S-2BTDI } \rightarrow \text { Left-Handed }\end{array}$ \\
\hline Pitch Length & $3.4 \mathrm{~nm}$ & $4.1 \mathrm{~nm}$ \\
\hline Diameter & $2 \mathrm{~nm}(\mathrm{~B}-\mathrm{DNA})$ & $1.6 \mathrm{~nm}$ \\
\hline $\begin{array}{l}\text { Noncovalent } \\
\text { Interactions }\end{array}$ & $\pi-\pi$ Stacking and Hydrogen Bonds & $\pi-\pi$ stacking and $[\mathrm{C}-\mathrm{H} \cdots \mathrm{O}]$ Hydrogen Bonds \\
\hline
\end{tabular}




\section{Section G. References}

(S1) Larrow, J. F.; Jacobsen, E. N. Org. Synth. 1998, 75, 1-11.

(S2) Dolomanov, O. V.; Bourhis, L. J.; Gildea, R. J.; Howard, J. A. K.; Puschmann, H. J. Appl. Crystallogr. 2009, 42, 339-341.

(S3) Sheldrick, G. Acta. Crystallogr. Sect. A 2015, 71, 3-8.

(S4) Sheldrick, G. Acta. Crystallogr. Sect. A 2008, 64, 112-122.

(S5) Shao, Y. et al, Mol. Phys. 2014, 113, 184.

(S6) Perdew, J. P.; Burke, K.; Ernzerhof, M. Phys. Rev. Lett. 1996, 77, 3865.

(S7) Grimme, S. J. Comput. Chem. 2006, 27, 1787.

(S8) Cossi, M.; Rega, N.; Scalmani, G.; Barone, V. J. Comput. Chem. 2003, 24, 669. 